\title{
Practices and opinions of teachers working at public, private and International Baccalaureate schools on measurement and evaluation
}

\author{
Merve YILDIRIM SEHERYELi*a , Selahattin GELBAL**b \\ ${ }^{a}$ Hasan Kalyoncu University, Faculty of Education, Gaziantep/Turkey \\ ${ }^{\mathrm{b}}$ Hacettepe University, Graduate School of Educational Sciences, Ankara/Turkey
}

Article Info

DOI: $10.31704 /$ ijocis.2020.008

Article History:

Received 21 March 2020

Revised 15 April 2020

Accepted 06 June 2020

Online 17 June 2020

Keywords: International

Baccalaureate (IB),

measurement, evaluation, assessment, teachers' opinions.

Article Type:

Research paper

\begin{abstract}
This study aims to investigate the opinions of teachers working at public, private, and International Baccalaureate (IB) Schools on the evaluation practices, the use of assessment tools, the frequency of documenting data, and the feedback frequencies given to both students, and parents. A questionnaire has been used to collect data from 168 teachers. 84 of these teachers were from public schools, 30 from IB, and 54 from private schools. Percentages and frequencies were examined to describe the data, and the chi-square test was conducted for their distribution. There are two main conclusions derived. The first one is that state schools and private schools differ from IB schools in terms of exam-oriented preparation and evaluations when traditional methods are employed. The second one is that IB schools differ from state schools and private schools in terms of documenting the data and reporting of assessment for learning improvement and process-based evaluation. In terms of teachers 'opinions, the ones from the IB schools believed there was a difference in terms of having an assessment policy, collaborative planning processes with partners, and experts, taking into consideration the individual differences, and having an inspection mechanism to monitor of the processes.
\end{abstract}

\begin{tabular}{lll}
\hline \multicolumn{2}{c}{ Devlet, özel ve Uluslararası Bakalorya okullarındaki öğretmenlerin ölçme ve } \\
değerlendirme çalışmaları ve görüşleri
\end{tabular}

* Author: yldrm.mrv.7806@gmail.com

** Author: sgelbal@gmail.com
Orcid ID: 0000-0002-1106-5358 Orcid ID: 0000-0001-5181-7262 


\section{Introduction}

The education system of each country gains functionality in line with the features of its curriculum. Two main approaches are mentioned while creating a curriculum. In the first one, curricula are thought of as a system and considered a complex whole of items serving common aims (Erden, 1998). Aims of education of any subject area can be determined and analyzed in advance within the scope of community and student characteristics. The content, method, and learning environment of education are specified within the frame of expert views, and studies. Evaluation means the level of achieving the goal (Demirel, 2012; Ertürk, 2013). Curriculum elements can be reviewed following the results of the evaluation (Demirel, 2012; Ertürk, 2013). However, in the second approach, student needs and processes are more prioritized than the outcome. The goal and process change constantly in accordance with the conditions in which the teaching is performed. For that reason, it is not possible to know them in advance (Erden, 1998). Also, students' and teachers'opinions, preferences, perceptions are more prominent than the expert opinions regarding the decisions to be taken for the curriculum (Demirel, 2012; Ertürk, 2013). Accordingly, the adopted design approach brings along the differentiation of the goals, educational status, content, measurement, and evaluation method.

The primary school curriculum proved in Turkey collectively in 1968 was revised based on the constructivist approach by the Ministry of National Education (MEB) between the years 2004-2005 (Yüksel \& Sağlam, 2014). The teacher is not the one who transfers the information directly but facilitates the students to reach the information in constructivism (Erdoğan, Kayır, Kaplan, Ünal \& Akbunar, 2015; Senemoğlu, 2012). Curriculum revision studies were carried out in 2013 and 2018. At all the curriculum that has been implemented since 2018, it is stated that it is not realistic to expect a standard measurement and evaluation process for each student, and thus importance should be given to variety. The flexibility of these processes, methods and techniques to be used by the teachers and educational practitioners are expected to be original and creative. It has also been pointed out that; not only the outcomes but also the processes should be looked into so that, tools and methods should in compliance with the technical, and academic standards, individual differences should be given importance cognitive-emotional, and psychomotor areas should also be assessed, and in the process of measurement and evaluation both the students and the teachers should take active roles (MEB, 2013; 2018; 2019). In the MEB 2023 Educational Vision, it is seen that these expectations evolved to targets like "establishment of proficiency-based measurement, and evaluation system", "monitoring of social, cultural and sportive activities", "monitoring the students from preschool to university with e-portfolio", "enabling measurement and evaluation methods". All the mentioned applications are expected from public schools as well as from all private schools supervised by the Ministry of National Education Private Education Institutions Regulation (2012).

Tough some studies include opinions of partners about conditions of learning and measurement and evaluation few of them focus on identifying the extent of fulfilling the expectations of MEB by schools and teachers. Gelbal and Kelecioğlu (2007) examined teacher opinions on constructivism based in-class measurement and evaluation methods. They've found that the teachers prefer traditional methods to determine student success; used the methods and techniques that they feel self-sufficient about frequently, and they used student evaluation methods the least frequently. The teachers who stated that they do not face any problems in using the methods also mentioned the high number of students in a classroom, inadequate time, and difficulty of tool preparation. In the study of Arda (2009), where competencies of primary school teachers, and their opinions about measurement, and evaluation were examined. The teachers mentioned the problems arising from students' lack of training in the use of constructivist assessment means and techniques stated in the renewed program. They stated that although they followed the measurement, and evaluation rules, students were not able to assess themselves and thus hold them responsible rather than the assessment tools for the failure. Besides, they also stated that the problems they encountered arose from physical setting, social environment, and parent profile, and the detailed, complex, and time-consuming characteristic 
Merve Yıldııım Seheryeli, Selahattin Gelbal- Uluslararası Eğitim Programları ve Öğretim Çalışmaları Dergisi, 10(1), 2020, 221-260 of measurement, and evaluation, and from the program itself. Gok and Sahin (2009) worked with 4th and 5th-grade teachers. The teachers considered themselves sufficient in using traditional evaluation methods, and therefore, did not prefer new evaluation methods. Another finding was that teachers needed help with the use of the new evaluation methods in terms of tool preparation and grading, and transforming the results on the school reports. Similar results were obtained by Yapıcı and Demirdelen (2007).

There are currently 54036 public, 12809 private, and four open education schools provide formal education with all levels in our country (MEB, 2019). Even though the same curricula are implemented at all of these schools, the practices differ according to the qualifications of teachers and practitioners, and the goals of the institutions. While these differences are more related to the qualifications of teachers in public schools, studies are carried out to serve the institutional policies of private schools. It is observed that private schools adopt different studies from public schools in order to increase the frequency of being preferred, and student and parent satisfaction. These activities can be sports, and artistic activities as well as using their curricula approved by MEB, or they can also differentiate these curricula with STEM (Science, Technology, Engineering ve Math) activities, or get accreditation from foreign institutions such as the International Baccalaureate Organization (IBO). In this study, International Baccalaureate (IB) schools were included along with the public and private schools. Only 79 of the schools in our country (2 public schools, 77 private schools) received accreditation as an IB school (IBO, t.y.).

The International Baccalaureate Organization (IBO) was established to realize an intercultural and global education system in Geneva, Switzerland. This foundation aims to stop children of diplomats, and people working at international jobs from preventing geographical, and cultural mobility of academic developments by establishing a standard education system (Ateş, 2011; IBO, 2012). IBO continues supporting lifelong learners as primary years program (PYP), middle years program (MYP), diploma program, and career-related program (CP). IBO aims to have a learner-centered, inquiry and research-based system using previously planned learning conditions to serve seven themes (who we are, where we are in place, and time, How we express ourselves, How we organize ourselves, Sharing the planet) with a supra-disciplinary approach, and raise individuals showing tolerance to differences, to enable academic honesty using measurement, and evaluation (IBO, 2012). In order to realize these aims, the expected skills are described under the "IB learner profile" title: inquirers, knowledgeable, thinker, communicator, principled, open-minded, caring, risk-taker, balanced reflective (IBO, 2018a; IBO, 2018b).

In IB measurement and evaluation, while process and product are evaluated together, support of teachers to their students, in order to enable them to evaluate, is prioritized. The teachers are expected to implement the assessment and evaluation in three stages: Assessing, documenting, and reporting. It is emphasized that all assessment tools and methods can be used concerning the individual differences of each student, including the process and product in assessing, and above all, learning should be supported with feedback (IBO, 2018c). It is also mentioned that students should be included in the evaluation process rather than being informed about their evaluation processes, criteria, and results. In the documentation stage, the importance of documenting the results of measurement tools, anecdotes, student reflections, and findings of student improvement is highlighted instead of just keeping them as an observation or teacher opinion. Furthermore, in this stage, all partners contributed or will contribute to the learning process of the student should provide verbal, and written, comprehensive, objective, and fair reports or sharings ( teacher-student, teacherparent, teacher-student-parent participated). Prior to these stages, a school should have its own measurement and evaluation policy, and the practices to be carried out under this policy should be carried out with the participation of all partners in the processes. Regular inspections by IBO also require all schools to carry out systematic measurement and evaluation activities (Büyükgenç, 2014; IBO, 2018d; IBO, 2012). 
Merve Yıldııım Seheryeli, Selahattin Gelbal- Uluslararası Eğitim Programları ve Öğretim Çalışmaları Dergisi, 10(1), 2020, 221-260

In the studies where the private schools which have completed their IBO accreditation processes are compared to other schools, issues like communication among family members, and social skills (Özeke Kocabaş \& Akkök, 2016), the difficulties that the school administration faced (Oraz, 2019) during the process of becoming an IB school are encountered. Moreover, in the studies on IB primary year program, teacher opinions about the program (Guler \& Yaltırık, 2011), applications, values, and beliefs of teachers (Twigg, 2010) were examined. In IB diploma program studies issues like teacher opinions on values education of schools in different countries (Şanver, 2016), reading habits of students. Their attitudes towards reading (Keleş, 2013); the effect of the program on the misconception about the plagiarism (Baysen, Baysen \& Çakmak, 2017), students' perception of learning climate (Bora, 2010), geography class taught in this program (Ates, 2011), the differences in its implementation (Kauffman, 2005), opinions of graduate students (Büyükgenç, 2014) are included. In all studies, it is said that the IB program has a positive effect on related features, and when compared to other schools, the IB program has more strong aspects. In addition to these studies, how the aim of educational evaluation is described in evaluation policies, and evaluation applications of schools was researched in action research conducted in a project which is carried out by Toe et al. (2015), and performed in eight different schools in IB primary years program. At the end of the research, it was seen that the teachers use formative and summative evaluation together; although there were differences in opinions about the integration of large scale tests into the system, the universal approach was dominant. They stated that the teachers make plans to describe the level of their students, improve their learnings, enable them to evaluation by considering individual differences as the main element, and to use different evaluation tools together. Besides, they also stated that they adopted the continuity in the development concept, and recorded the information they obtained and emphasized the importance of feedback rather than personal praise. These results are in line with the studies of Güler and Yaltırık (2011) and Oraz (2019).

With these in mind, the present study focuses on the measurement and evaluation studies of teachers working at IB schools in Turkey, and public and private schools under the Ministry of National Education, and their opinions on this issue. One of the essential reasons is that students who graduate from IB schools can apply to European universities with different university entrance opportunities (university entrance without exam, meeting the university criteria, etc.). Therefore, as an alternative to the educational process in our country, the measurement and evaluation processes need to be looked into differing school types and perspectives of study groups especially teachers and implementation of the measurement and evaluation approaches proposed in the curriculum for all types of schools by teachers. Also, employing efficient methods from other schools can help reduce the differences between different types of schools. As a result of this contribution, especially when these differences are reduced, the bias problem of the measurements of the evaluation may also be reduced. Therefore, it is thought that preliminary information can be provided on issues such as "fairness", "bias", "differential item functioning" and "measurement invariance", which are frequently discussed in the field of measurement and evaluation.

\section{Purpose of the Research}

The purpose of this research is to examine the opinions of teachers working at public, private, and International Baccalaureate Schools on measurement, and evaluation studies, use of measurement, and evaluation strategies, and methods, documenting of information, and the feedback frequencies given to both students, and parents. In accordance with this purpose, answers to below-stated subproblems are sought.

1. Which concepts do teachers working at public schools, private schools, and IB schools relate "Measurement, and evaluation" with?

2. Does the thought of being liable to a measurement and evaluation system show a significant difference? How do the teachers who are in the opinion of being liable to a system contribute to this system? 
Merve Yıldırım Seheryeli, Selahattin Gelbal- Uluslararası Eğitim Programları ve Öğretim Çalışmaları Dergisi, 10(1), 2020, 221-260

3. Is there a significant difference among teachers of public schools, private schools, and IB schools regarding the frequencies of;

1. the use of different measurement, and evaluation techniques,

2. (i) documenting the results of measurement and evaluation

(ii) sharing the results with the students

(iii) sharing the results with the parents

\section{Method}

The opinions of teachers working at different types of schools on measurement, and evaluation studies, use of assessment tools, documentation of the data, and the feedback frequencies given to both students and parents were examined in this study. Thus, survey research was used as it aims to describe, and transfer the present state, individuals or objects in their conditions without making any change (Büyüköztürk, Çakmak, Akgün, Karadeniz \& Demirel, 2019).

\section{Population and Sampling}

The population of this research includes teachers teaching at public schools in Turkey, IB candidate/IB schools, and private schools in the 2019-2020 academic year. 54036 teachers from public schools, 12809 from private schools (MEB, 2019), and 77 from IB schools participated in the study. Therefore, $80.8 \%$ of all schools participating in this study were public, $19.1 \%$ were private, and $0.1 \%$ were IB schools (IBO, t.y.).

The sample of this research was identified as convenience sampling which is one of the nonrandom sampling methods and aims to eliminate the limits (Büyüköztürk et al., 2019) caused by time, money, and workforce. However it was aimed to reach more teachers at the first stage of the research since a limited number of individuals can be reached, the sampling effect is the most important factor affecting the external validity of this research.

In this sample, 168 teachers are working at an IB school, IB candidate school, public school, or private school at 23 different provinces in the 2019-2020 academic year. 84 (50\%) of the teachers were teaching at public schools, $30(18 \%)$ at IB schools (6 at IB candidate schools), and $54(32 \%)$ at private schools. As the number of participants in the IB candidate school was small, they were merged with IB school participants. Since this study aims to compare schools in terms of the assessed characteristics, the number of teachers working in IB primary years, middle years, and schools implementing diploma programs were kept higher than the ratio of schools of population. $95(56 \%)$ of the participants are women, and $73(44 \%)$ are men. $26(16 \%)$ of the participants work in preschool, $44(26 \%)$ in primary school, $51(31 \%)$ in secondary school, and $52(31 \%)$ in high school (teachers are working in more than one level.). It is seen that the number of teachers who completed or continue their postgraduate education is $31(37 \%)$ in public school, $19(63 \%)$ in IB school, $14(26 \%)$ in private school. When the participants' experiences were analyzed, it was observed that 52 (62\%) of teachers in public schools, 8 $(27 \%)$ of teachers in IB schools, and $24(44 \%)$ of teachers in private schools had an experience of 10 years or less.

\section{Data Collection Tool}

A questionnaire prepared by researches was used to collect data. For the appropriateness of the questions, expert advice was received from five people; three of them were academicians in the field of measurement and evaluation, and two of them were in the curriculum and teaching field. Four of the experts worked as educators at the International Baccalaureate Educator Certificate program. The experts agreed on the appropriateness of all the questions, and suggested customizing the form designs for IB and edit on the text. The differentiated questions for IC teachers were as follows:

"What is your total working time as a teacher at an IB school" "The IB Program you work at: " "What does "measurement and evaluation" mean for teachers working at MEB? Can you explain it?" 
Merve Yıldırım Seheryeli, Selahattin Gelbal- Uluslararası Eğitim Programları ve Öğretim Çalışmaları Dergisi, 10(1), 2020, 221-260

In the first section of the survey demographic characteristics of participants, and their description of measurement, and evaluation; in the second section, measurement, and evaluation tools, documenting, and frequency of using it to give feedback, and in the third section, their opinions on the difficulties they faced, and suggestions to project partners were included. The questionnaire consisting of 26 questions in total was posted on the Internet by using "Google Forms" in the Google browser. The answers were given to the questions about the difficulties they experienced in the questionnaire, and the suggestions to the partners' section were not reported because of the similarities to the answers of other questions and the word limitation.

\section{Data Analysis}

The quantitative data included in the first section of the questionnaire was analyzed with SPSS 25 Program. Percentages and frequencies were used for the description of the data through data analysis, and chi-square $\left(\chi^{2}\right)$ test was used for frequency distributions. Moreover, descriptive analyses were done for the answers given to open-ended questions. In the descriptive analysis, the most common concepts used by teachers were identified and listed under titles. The concepts seen on the tables were limited to at least two or three frequencies, and concepts with one frequency were added to make some comparisons.

\section{Ethic Issues}

Data of the research was collected via the Internet on a volunteer basis. For that reason, in the instruction prepared for the participants it is stated that their names will not be saved, their answers will not be used for any other purposes rather than this research, they have the right not to participate in the study, and leave the study at any time after their participation, and there will not be any money exchanged for their participation. Additionally, the below-stated explanation was also included in the instruction section. By clicking the "Submit" button at the end of the form, you will declare that you agree with the statement below. "I have understood all the explanations made to me about the research in detail. I agree with this work with my consent under no influence."

\section{Results}

\section{Concepts Related to Assessment and Evaluation}

The answers of teachers to open-ended questions were analyzed in the data obtained via "what are the concepts that come to the minds first of teachers in public schools, IB schools, and private schools when "measurement, and evaluation" mentioned?" question. It was seen that all opinions could be grouped under five main titles namely as determined as "Basic Concepts," "Statistics," "What Do We Assess?", "Why do We Assess?" and "How Do We Assess?"

The keywords of the "Basic Concepts" group title for each school type were validity, reliability, scale, criteria, evaluation, fairness, process evaluation. 76 teachers from the public school, 22 from the private school, and 26 from the IB school stated their opinions about the basic concepts of measurement and evaluation. The most prominent concepts were validity and reliability in public schools, validity, and process evaluation in private schools, process, and product evaluation in IB schools. However, it can be said that fairness and holistic assessment concepts were only mentioned in IB schools.

The key words collected under the "Statistics" title for each school type were standard deviation, difficulty, discrimination, mode-median, item analysis. 29 teachers from public schools, 9 from private schools, and 2 from IB schools mentioned these keywords. The most prominent keywords were standard deviation, and item difficulty in public schools, item analysis, and standard deviation in private schools, and similarly, item analysis in IB schools. 
Merve Yıldırım Seheryeli, Selahattin Gelbal- Uluslararası Eğitim Programları ve Öğretim Çalışmaları Dergisi, 10(1), 2020, 221-260

The keywords collected under the "What do we assess?" title for each school type were achievement, performance, success, learning level, taxonomy, symptom, process, skill, acquisition. 49 teachers from public schools, 22 from private schools, and 21 from IB schools stated the mentioned keywords. The most prominent concepts were acquisition and performance in public schools; success, and acquisition in private schools; process, achievement, and skill in IB schools.

The keywords collected under the "Why do we assess" title for each school type were feedback, quality of education, and motivation of the student, determining the situation, reflective thinking, improving quality, identifying deficiencies, differentiating, improving learning, planning, reporting. 28 teachers from public schools, 12 from private schools, and 36 from IB schools answered the mentioned question. The most prominent concept was feedback. Producing solutions, reflective thinking, differentiation, needs assessment, planning, and reporting were the concepts solely provided by IB school teachers.

The keywords collected under "How do we assess" title for each school type were an exam, question, written exam, observation, point, open-ended, multiple-choice, grade, portfolio, rubric, process analysis, reflecting, group work, and homework. 91 teachers from public schools, 46 from private schools, and 21 from IB schools had answered the question. It was seen that the most prominent concepts were an exam, question, and test in public schools, exams, tests, and rubric in private schools, and rubric, and process-oriented tools in IB schools. It can be said that the concepts stated only in IB schools were anecdote, presentation, and reflection.

\section{Opinions about measurement, and evaluation system, and contributions to the system}

Chi-square difference test results concerning the "Do the teachers working at public school, private school, and IB school think that they are liable to measurement, and evaluation system?" question are presented in the Table 1.

Table 1.

The Chi-Square Test Results Concerning the Opinions Of Teachers about the Presence of Measurement, and Evaluation System in Their Schools

\begin{tabular}{|c|c|c|c|c|c|c|c|}
\hline & & Yes & No & Total & Chi-square & df & $\mathbf{p}$ \\
\hline \multirow[t]{2}{*}{ Public School } & $\mathrm{N}$ & 40 & 44 & 84 & 34.531 & 2 & $0.000 *$ \\
\hline & $\%$ & $47.6 \%$ & $52.4 \%$ & $100.0 \%$ & & & \\
\hline \multirow[t]{2}{*}{ IB School } & $\mathrm{N}$ & 25 & 5 & 30 & & & \\
\hline & $\%$ & $83.3 \%$ & $16.7 \%$ & $100.0 \%$ & & & \\
\hline \multirow[t]{2}{*}{ Private School } & $\mathrm{N}$ & 50 & 4 & 54 & & & \\
\hline & $\%$ & $92.6 \%$ & $7.4 \%$ & $100.0 \%$ & & & \\
\hline \multirow[t]{2}{*}{ Total } & $\mathrm{N}$ & 115 & 53 & 168 & & & \\
\hline & $\%$ & $68.5 \%$ & $31.5 \%$ & $100.0 \%$ & & & \\
\hline
\end{tabular}

$* p<0.05$

Table 1 shows that, while $48 \%$ of the teachers working in public schools believe that they do have a measurement and evaluation system yet $52 \%$ think the opposite. $83 \%$ of the teachers in IB schools think that there is an applied measurement and evaluation system at the schools they are working at, and $17 \%$ do not. While the rate of teachers who think that they do not have a measurement and evaluation system falls to $7 \%$ in private schools, and the rate of those who think that the system exists has increased to $93 \%$. This differentiation between the ratios was found statistically significant at the level of $0.05(\chi 2=34.531 ; s d=2 ; p<0.05)$. Their opinions about whether there is a measurement and evaluation system in their schools vary according to the type of school.

When the activities of the teachers, who think that there is a measurement, and evaluation system in their schools, to apply this measurement, and evaluation system in their schools are analyzed, it has been observed that these activities are collected under five titles which are "Placement", " 
Merve Yıldırım Seheryeli, Selahattin Gelbal- Uluslararası Eğitim Programları ve Öğretim Çalışmaları Dergisi, 10(1), 2020, 221-260 Reinforcement of learning", "Contribution to the quality of the system", "Evaluation," and "Documenting."

The keywords collected for each school type under the title of "Placement" were written exam, question-answer, oral exam, outcome evaluation, ready-made tests, questions prepared by teachers based on outcome or taxonomy, new generation questions, test, and assessment of skills. The teachers who stated that they have a measurement and evaluation system in their schools and apply placement studies to actualize this system stated 32 opinions in public schools, 39 opinions in private schools, and 14 opinions in IB schools.

The keywords for "Learning Reinforcement" are homework, praising or grading punishment, repetition, inquiry studies. The teachers who stated that they have a measurement and evaluation system in their schools and perform learning reinforcement studies to actualize this system stated eight opinions in public schools, four opinions in private schools, and five opinions in IB schools. The most prominent learning reinforcement studies were homework, and repetition in public schools; repetition in private schools, and inquiry studies in IB schools. It can be said that the studies that are carried only in IB schools are inquiry studies.

The keywords for "Contribution to the Quality of the System" are acting fairly, making it more enjoyable, group cooperation, butterfly system, comfortable classroom environments, Web 2.0 tools, making it understandable, having an R\&D team, considering individual differences, associating with daily life, inter-disciplinary working, using a plagiarism program, setting the criteria with the students or informing the students about the criteria. The teachers, who stated that they have a measurement and evaluation system in their schools, and carry out studies that contribute to the quality of the system to actualize this system, stated 8 opinions in public schools, 11 opinions in private schools, and 15 opinions in IB schools. In this regard, the most prominent practices were acting fairly in public schools; considering individual differences, and group cooperation in private schools, and interdisciplinary working, and group cooperations, and setting the criteria with the students or informing the students about the criteria in IB schools. It can be said that the studies that are seen only in IB schools are about acting fairly, the R\&D team, enabling active participation of students in the measurement, and evaluation processes, and the studies saw only in private schools are butterfly systems, plagiarism programs, and Web 2.0 tools.

The key words collected for each school type under the "Evaluation" title are feedback, observation forms, performance evaluation, portfolio, self-peer assessment, process-oriented evaluation, rubric, criteria-based evaluation. The teachers who stated that they have a measurement and evaluation system in their schools and apply evaluation studies to actualize this system stated 26 opinions in public schools, 35 opinions in private schools, and 20 opinions in IB schools. The most prominent evaluation studies were feedback and performance in public schools, feedback, and process-oriented evaluation in private schools, and rubric, and process-oriented evaluation in IB schools. It can be said that studies that were seen only in IB schools are self-awareness, scales, and rubric.

The keywords for the "Documentation title" are analysis results, improvement reports, and education planning. The teachers who stated that they have a measurement and evaluation system in their schools, and document information to actualize this system stated two opinions from public schools, one opinion from private schools, and ten opinions from IB schools. Even though the analysis and reporting studies were mentioned once, planning and education planning studies have become prominent in IB schools.

\section{Frequency of using tools, and techniques, documenting, and sharing of the information}

Teachers were asked to grade 10 different measurements, and evaluation tools, and techniques ranging from 1 to 6 as "1: Never, 2: Once a year, three maximum once in a semester, 4: Once a month, 5: Once a week, 6: Always". The data obtained were grouped under four headings as the frequency of teachers' using (a) tools, and techniques, (b) documenting, (c) sharing them with students, and (d) 
Merve Yıldııım Seheryeli, Selahattin Gelbal- Uluslararası Eğitim Programları ve Öğretim Çalışmaları Dergisi, 10(1), 2020, 221-260 parents. A chi-square difference test was conducted on whether these four topics differed among schools or not. In order to interpret the results related to the significance test at the level of 0.05 correctly, it is essential that the expected value of the number of rows being less than five should not exceed $20 \%$ (Field, 2009). For this reason, the number of rows was examined, categories 1, 2, and 3 were combined as "maximum once in a semester", and categories 5 and 6 were combined as "at least once a week."

The chi-square test results of public and IB schools concerning the frequency of using measurement and evaluation tools/techniques are stated in Table 2. Categories 1, 2, 3, and four are combined as "at least once a month" to provide the ratio expected to be less than $20 \%$ in the frequency tables of "monitoring" of students and "feedback."

Table 2 demonstrates that the frequency of teachers' observing students, and giving feedback, performance evaluation (presentation, discussion, role play, etc.), multiple-choice questions, and using open-ended tasks are at least once a week in all three school types, and the frequency of using portfolio is at most once in all three school types. These frequencies did not differ according to school type $(p<0.05)$. Therefore, values related to these tools and techniques are not included in the table.

Table 2.

Results of the Chi-Square Test Regarding the Frequency of Use of Measurement, and Evaluation Tools, and Techniques According to the Type of School They Work

\begin{tabular}{|c|c|c|c|c|c|c|c|c|c|}
\hline & & & $\begin{array}{c}\text { Maximum } \\
\text { once in a } \\
\text { semester }\end{array}$ & $\begin{array}{l}\text { Once a } \\
\text { month }\end{array}$ & $\begin{array}{c}\text { At least } \\
\text { once a } \\
\text { week }\end{array}$ & Total & $\begin{array}{c}\text { Chi- } \\
\text { square }\end{array}$ & df & $\mathbf{p}$ \\
\hline Self & Public School & $\mathrm{N}$ & 40 & 16 & 28 & 84 & 18.074 & 4 & $0.001 *$ \\
\hline \multirow[t]{7}{*}{ Assessment } & & $\%$ & $47.6 \%$ & $19.0 \%$ & $33.3 \%$ & $100.0 \%$ & & & \\
\hline & IB School & $\mathrm{N}$ & 6 & 2 & 22 & 30 & & & \\
\hline & & $\%$ & $20.0 \%$ & $6.7 \%$ & $73.3 \%$ & $100.0 \%$ & & & \\
\hline & Private School & $\mathrm{N}$ & 14 & 13 & 27 & 54 & & & \\
\hline & & $\%$ & $25.9 \%$ & $24.1 \%$ & $50.0 \%$ & $100.0 \%$ & & & \\
\hline & Total & $\mathrm{N}$ & 60 & 31 & 77 & 168 & & & \\
\hline & & $\%$ & $35.7 \%$ & $18.5 \%$ & $45.8 \%$ & $100.0 \%$ & & & \\
\hline Peer & Public School & $\mathrm{N}$ & 50 & 9 & 25 & 84 & 19.675 & 4 & $0.001 *$ \\
\hline \multirow[t]{7}{*}{ Assessment } & & $\%$ & $59.5 \%$ & $10.7 \%$ & $29.8 \%$ & $100.0 \%$ & & & \\
\hline & IB School & $\mathrm{N}$ & 6 & 9 & 15 & 30 & & & \\
\hline & & $\%$ & $20.0 \%$ & $30.0 \%$ & $50.0 \%$ & $100.0 \%$ & & & \\
\hline & Private School & $\mathrm{N}$ & 17 & 11 & 26 & 54 & & & \\
\hline & & $\%$ & $31.5 \%$ & $20.4 \%$ & $48.1 \%$ & $100.0 \%$ & & & \\
\hline & Total & $\mathrm{N}$ & 73 & 29 & 66 & 168 & & & \\
\hline & & $\%$ & $43.5 \%$ & $17.3 \%$ & $39.3 \%$ & $100.0 \%$ & & & \\
\hline \multirow[t]{8}{*}{ Checklist } & Public School & $\mathrm{N}$ & 42 & 14 & 28 & 84 & 12.856 & 4 & $0.012 *$ \\
\hline & & $\%$ & $50.0 \%$ & $16.7 \%$ & $33.3 \%$ & $100.0 \%$ & & & \\
\hline & IB School & $\mathrm{N}$ & 5 & 7 & 18 & 30 & & & \\
\hline & & $\%$ & $16.7 \%$ & $23.3 \%$ & $60.0 \%$ & $100.0 \%$ & & & \\
\hline & Private School & $\mathrm{N}$ & 16 & 11 & 27 & 54 & & & \\
\hline & & $\%$ & $29.6 \%$ & $20.4 \%$ & $50.0 \%$ & $100.0 \%$ & & & \\
\hline & Total & $\mathrm{N}$ & 63 & 32 & 73 & 168 & & & \\
\hline & & $\%$ & $37.5 \%$ & $19.0 \%$ & $43.5 \%$ & $100.0 \%$ & & & \\
\hline \multirow[t]{5}{*}{ Rubric } & Public School & $\mathrm{N}$ & 51 & 10 & 23 & 84 & 17.345 & 4 & $0.002 *$ \\
\hline & & $\%$ & $60.7 \%$ & $11.9 \%$ & $27.4 \%$ & $100.0 \%$ & & & \\
\hline & IB School & $\mathrm{N}$ & 6 & 5 & 19 & 30 & & & \\
\hline & & $\%$ & $20.0 \%$ & $16.7 \%$ & $63.3 \%$ & $100.0 \%$ & & & \\
\hline & Private School & $\mathrm{N}$ & 21 & 9 & 24 & 54 & & & \\
\hline
\end{tabular}


Merve Yıldırım Seheryeli, Selahattin Gelbal- Uluslararası Eğitim Programları ve Öğretim Çalışmaları Dergisi, 10(1), 2020, 221-260

$\begin{array}{ccccccc}\text { Table 2 } & \% & 38.9 \% & 16.7 \% & 44.4 \% & 100.0 \% \\ \text { (Cont.) } & & \mathrm{N} & 78 & 24 & 66 & 168 \\ & \text { Total } & \% & 46.4 \% & 14.3 \% & 39.3 \% & 100.0 \%\end{array}$

$* p<0.05$.

While the majority of the teachers working at public schools stated that they use the self and peer assessment, checklists, and rubric once in a semester at most, the majority of the ones from the private schools and IB schools said they use them at least once a week. The highest frequency is "at least once a week" in IB schools. These differences between the rates significant at the 0.05 level. While the frequency of use in IB schools, and private schools was at least once a week in general, the frequency of use in public schools was at most once in the period.

The results of the chi-square test regarding the frequency of documenting the information collected through measurement and evaluation by the teachers working in public schools, IB schools, and private schools are given in Table 3.

Table 3.

Documenting the Measurement and Evaluation Results of Teachers for Each School Type

\begin{tabular}{|c|c|c|c|c|c|c|c|c|c|}
\hline & & & $\begin{array}{l}\text { Maximum } \\
\text { once in a } \\
\text { semester }\end{array}$ & $\begin{array}{l}\text { Once a } \\
\text { month }\end{array}$ & $\begin{array}{c}\text { At least } \\
\text { once a } \\
\text { week }\end{array}$ & Total & Chi-square & df & $\mathbf{p}$ \\
\hline \multirow{8}{*}{$\begin{array}{l}\text { Student } \\
\text { Monitoring }\end{array}$} & \multirow[t]{2}{*}{ Public School } & $\mathrm{N}$ & 28 & 12 & 44 & 84 & 10.145 & 4 & $0.038^{*}$ \\
\hline & & $\%$ & $33.3 \%$ & $14.3 \%$ & $52.4 \%$ & $100.0 \%$ & & & \\
\hline & \multirow[t]{2}{*}{ IB School } & $\mathrm{N}$ & 5 & 1 & 24 & 30 & & & \\
\hline & & $\%$ & $16.7 \%$ & $3.3 \%$ & $80.0 \%$ & $100.0 \%$ & & & \\
\hline & \multirow[t]{2}{*}{ Private School } & $\mathrm{N}$ & 10 & 5 & 39 & 54 & & & \\
\hline & & $\%$ & $18.5 \%$ & $9.3 \%$ & $72.2 \%$ & $100.0 \%$ & & & \\
\hline & \multirow[t]{2}{*}{ Total } & $\mathrm{N}$ & 43 & 18 & 107 & 168 & & & \\
\hline & & $\%$ & $25.6 \%$ & $10.7 \%$ & $63.7 \%$ & $100.0 \%$ & & & \\
\hline \multirow[t]{8}{*}{ Feedback } & \multirow[t]{2}{*}{ Public School } & $\mathrm{N}$ & 28 & 14 & 42 & 84 & 12.594 & 4 & $0.013^{*}$ \\
\hline & & $\%$ & $33.3 \%$ & $16.7 \%$ & $50.0 \%$ & $100.0 \%$ & & & \\
\hline & \multirow[t]{2}{*}{ IB School } & $\mathrm{N}$ & 5 & 1 & 24 & 30 & & & \\
\hline & & $\%$ & $16.7 \%$ & $3.3 \%$ & $80.0 \%$ & $100.0 \%$ & & & \\
\hline & \multirow[t]{2}{*}{ Private School } & $\mathrm{N}$ & 8 & 8 & 38 & 54 & & & \\
\hline & & $\%$ & $14.8 \%$ & $14.8 \%$ & $70.4 \%$ & $100.0 \%$ & & & \\
\hline & \multirow[t]{2}{*}{ Total } & $\mathrm{N}$ & 41 & 23 & 104 & 168 & & & \\
\hline & & $\%$ & $24.4 \%$ & $13.7 \%$ & $61.9 \%$ & $100.0 \%$ & & & \\
\hline \multirow{8}{*}{$\begin{array}{l}\text { Performance } \\
\text { Evaluation } \\
\text { (presentation, } \\
\text { discussion, role } \\
\text { play, etc.) }\end{array}$} & \multirow{2}{*}{ Public School } & $\mathrm{N}$ & 39 & 15 & 30 & 84 & 16.759 & 4 & $0.002^{*}$ \\
\hline & & $\%$ & $46.4 \%$ & $17.9 \%$ & $35.7 \%$ & $100.0 \%$ & & & \\
\hline & \multirow[t]{2}{*}{ IB School } & $\mathrm{N}$ & 3 & 6 & 21 & 30 & & & \\
\hline & & $\%$ & $10.0 \%$ & $20.0 \%$ & $70.0 \%$ & $100.0 \%$ & & & \\
\hline & \multirow[t]{2}{*}{ Private School } & $\mathrm{N}$ & 14 & 9 & 31 & 54 & & & \\
\hline & & $\%$ & $25.9 \%$ & $16.7 \%$ & $57.4 \%$ & $100.0 \%$ & & & \\
\hline & \multirow[t]{2}{*}{ Total } & $\mathrm{N}$ & 56 & 30 & 82 & 168 & & & \\
\hline & & $\%$ & $33.3 \%$ & $17.9 \%$ & $48.8 \%$ & $100.0 \%$ & & & \\
\hline \multirow[t]{8}{*}{ Portfolio } & \multirow[t]{2}{*}{ Public School } & $\mathrm{N}$ & 58 & 6 & 20 & 84 & 17.698 & 4 & $0.001 *$ \\
\hline & & $\%$ & $69.0 \%$ & $7.1 \%$ & $23.8 \%$ & $100.0 \%$ & & & \\
\hline & \multirow[t]{2}{*}{ IB School } & $\mathrm{N}$ & 14 & 0 & 16 & 30 & & & \\
\hline & & $\%$ & $46.7 \%$ & $0.0 \%$ & $53.3 \%$ & $100.0 \%$ & & & \\
\hline & \multirow[t]{2}{*}{ Private School } & $\mathrm{N}$ & 25 & 10 & 19 & 54 & & & \\
\hline & & $\%$ & $46.3 \%$ & $18.5 \%$ & $35.2 \%$ & $100.0 \%$ & & & \\
\hline & \multirow[t]{2}{*}{ Total } & $\mathrm{N}$ & 97 & 16 & 55 & 168 & & & \\
\hline & & $\%$ & $57.7 \%$ & $9.5 \%$ & $32.7 \%$ & $100.0 \%$ & & & \\
\hline
\end{tabular}


Merve Yıldırım Seheryeli, Selahattin Gelbal- Uluslararası Eğitim Programları ve Öğretim Çalışmaları Dergisi, 10(1), 2020, 221-260 Table 3 (Cont.)

\begin{tabular}{|c|c|c|c|c|c|c|c|c|c|}
\hline \multirow{2}{*}{\multicolumn{2}{|c|}{ Self-assessment Public School }} & $\mathrm{N}$ & 47 & 10 & 27 & 84 & 22.201 & 4 & $0.000^{*}$ \\
\hline & & $\%$ & $56.0 \%$ & $11.9 \%$ & $32.1 \%$ & $100.0 \%$ & & & \\
\hline & \multirow[t]{2}{*}{ IB School } & $\mathrm{N}$ & 5 & 2 & 23 & 30 & & & \\
\hline & & $\%$ & $16.7 \%$ & $6.7 \%$ & $76.7 \%$ & $100.0 \%$ & & & \\
\hline & \multirow[t]{2}{*}{ Private School } & $\mathrm{N}$ & 17 & 10 & 27 & 54 & & & \\
\hline & & $\%$ & $31.5 \%$ & $18.5 \%$ & $50.0 \%$ & $100.0 \%$ & & & \\
\hline & \multirow[t]{2}{*}{ Total } & $\mathrm{N}$ & 69 & 22 & 77 & 168 & & & \\
\hline & & $\%$ & $41.1 \%$ & $13.1 \%$ & $45.8 \%$ & $100.0 \%$ & & & \\
\hline \multirow{8}{*}{$\begin{array}{l}\text { Peer } \\
\text { assessment }\end{array}$} & \multirow[t]{2}{*}{ Public School } & $\mathrm{N}$ & 54 & 8 & 22 & 84 & 20.725 & 4 & $0.000 *$ \\
\hline & & $\%$ & $64.3 \%$ & $9.5 \%$ & $26.2 \%$ & $100.0 \%$ & & & \\
\hline & \multirow[t]{2}{*}{ IB School } & $\mathrm{N}$ & 7 & 3 & 20 & 30 & & & \\
\hline & & $\%$ & $23.3 \%$ & $10.0 \%$ & $66.7 \%$ & $100.0 \%$ & & & \\
\hline & \multirow[t]{2}{*}{ Private School } & $\mathrm{N}$ & 20 & 8 & 26 & 54 & & & \\
\hline & & $\%$ & $37.0 \%$ & $14.8 \%$ & $48.1 \%$ & $100.0 \%$ & & & \\
\hline & \multirow[t]{2}{*}{ Total } & $\mathrm{N}$ & 81 & 19 & 68 & 168 & & & \\
\hline & & $\%$ & $48.2 \%$ & $11.3 \%$ & $40.5 \%$ & $100.0 \%$ & & & \\
\hline \multirow[t]{8}{*}{ Checklist } & \multirow[t]{2}{*}{ Public School } & $\mathrm{N}$ & 51 & 11 & 22 & 84 & 22.818 & 4 & $0.000 *$ \\
\hline & & $\%$ & $60.7 \%$ & $13.1 \%$ & $26.2 \%$ & $100.0 \%$ & & & \\
\hline & \multirow[t]{2}{*}{ IB School } & $\mathrm{N}$ & 5 & 4 & 21 & 30 & & & \\
\hline & & $\%$ & $16.7 \%$ & $13.3 \%$ & $70.0 \%$ & $100.0 \%$ & & & \\
\hline & \multirow[t]{2}{*}{ Private School } & $\mathrm{N}$ & 19 & 9 & 26 & 54 & & & \\
\hline & & $\%$ & $35.2 \%$ & $16.7 \%$ & $48.1 \%$ & $100.0 \%$ & & & \\
\hline & \multirow[t]{2}{*}{ Total } & $\mathrm{N}$ & 75 & 24 & 69 & 168 & & & \\
\hline & & $\%$ & $44.6 \%$ & $14.3 \%$ & $41.1 \%$ & $100.0 \%$ & & & \\
\hline \multirow{8}{*}{$\begin{array}{l}\text { Grading Key } \\
\text { (Rubric) }\end{array}$} & \multirow[t]{2}{*}{ Public School } & $\mathrm{N}$ & 52 & 10 & 22 & 84 & 23.61 & 4 & $0.000 *$ \\
\hline & & $\%$ & $61.9 \%$ & $11.9 \%$ & $26.2 \%$ & $100.0 \%$ & & & \\
\hline & \multirow[t]{2}{*}{ IB School } & $\mathrm{N}$ & 6 & 3 & 21 & 30 & & & \\
\hline & & $\%$ & $20.0 \%$ & $10.0 \%$ & $70.0 \%$ & $100.0 \%$ & & & \\
\hline & \multirow[t]{2}{*}{ Private School } & $\mathrm{N}$ & 19 & 11 & 24 & 54 & & & \\
\hline & & $\%$ & $35.2 \%$ & $20.4 \%$ & $44.4 \%$ & $100.0 \%$ & & & \\
\hline & \multirow[t]{2}{*}{ Total } & $\mathrm{N}$ & 77 & 24 & 67 & 168 & & & \\
\hline & & $\%$ & $45.8 \%$ & $14.3 \%$ & $39.9 \%$ & $100.0 \%$ & & & \\
\hline
\end{tabular}

${ }^{*} p<0.05$.

The data on Table 3 reveals that the highest frequency rate of documenting the information obtained by teachers by observing students, and feedback in every school type is at least once a week, but this rate is higher in IB schools than others. It is also seen that the highest frequency rate of the public and private school teachers to record the information they obtained through the portfolio was maximum once in a semester, and the highest rate of this frequency in IB schools was s at least once a week. While they stated with the highest rate that they recorded the information they obtained through the use of performance evaluation, self, and peer assessment, checklists, and grading key at most maximum once in a semester in public schools, while in the private schools, and IB schools they recorded them at least once a week. These differences between the rates were found significant at the 0.05 level. The highest value of these rates was observed in IB schools.

The frequency of documenting the information collected through multiple-choice questions in public schools, and IB schools varied from at most maximum once in a semester, toat least once a month in private schools. Nevertheless, the highest frequency of documenting the information collected through the use of open-ended tasks was at least once a week in every school type. These rates did not show significant differences $(p<0.05)$. Therefore, the values related to these frequencies 
Merve Yıldırım Seheryeli, Selahattin Gelbal- Uluslararası Eğitim Programları ve Öğretim Çalışmaları Dergisi, 10(1), 2020, 221-260 were not included in the table. The frequency of documented information collected from multiplechoice questions and open-ended tasks in public schools, IB schools, and private schools do not change.

The results of the chi-square test of teachers working in public school, IB school, and private schools regarding the frequency of sharing the measurement and evaluation results with students have been given in Table 4.

Table 4.

Chi-Square Test Results about the Frequency of Teachers' Sharing the Measurement and Evaluation Results with Students According to the School They Work At

\begin{tabular}{|c|c|c|c|c|c|c|c|c|c|}
\hline & & & $\begin{array}{l}\text { Maximum } \\
\text { once in a } \\
\text { semester }\end{array}$ & $\begin{array}{l}\text { Once a } \\
\text { month }\end{array}$ & $\begin{array}{l}\text { At least once } \\
\text { a week }\end{array}$ & Total & Chi-square & df & $\mathbf{p}$ \\
\hline \multirow{8}{*}{$\begin{array}{l}\text { Student } \\
\text { monitoring }\end{array}$} & Public School & $\mathrm{N}$ & 30 & 9 & 45 & 84 & 10.368 & 4 & $0.035^{*}$ \\
\hline & & $\%$ & $35.7 \%$ & $10.7 \%$ & $53.6 \%$ & $100.0 \%$ & & & \\
\hline & IB School & $\mathrm{N}$ & 4 & 1 & 25 & 30 & & & \\
\hline & & $\%$ & $13.3 \%$ & $3.3 \%$ & $83.3 \%$ & $100.0 \%$ & & & \\
\hline & Private School & $\mathrm{N}$ & 12 & 8 & 34 & 54 & & & \\
\hline & & $\%$ & $22.2 \%$ & $14.8 \%$ & $63.0 \%$ & $100.0 \%$ & & & \\
\hline & Total & $\mathrm{N}$ & 46 & 18 & 104 & 168 & & & \\
\hline & & $\%$ & $27.4 \%$ & $10.7 \%$ & $61.9 \%$ & $100.0 \%$ & & & \\
\hline \multirow{8}{*}{$\begin{array}{l}\text { Performance } \\
\text { Evaluation } \\
\text { (presentation, } \\
\text { discussion, role } \\
\text { play, etc.) }\end{array}$} & Public School & $\mathrm{N}$ & 43 & 10 & 31 & 84 & 17.97 & 4 & $0.001 *$ \\
\hline & & $\%$ & $51.2 \%$ & $11.9 \%$ & $36.9 \%$ & $100.0 \%$ & & & \\
\hline & IB School & $\mathrm{N}$ & 4 & 5 & 21 & 30 & & & \\
\hline & & $\%$ & $13.3 \%$ & $16.7 \%$ & $70.0 \%$ & $100.0 \%$ & & & \\
\hline & Private School & $\mathrm{N}$ & 16 & 13 & 25 & 54 & & & \\
\hline & & $\%$ & $29.6 \%$ & $24.1 \%$ & $46.3 \%$ & $100.0 \%$ & & & \\
\hline & Total & $\mathrm{N}$ & 63 & 28 & 77 & 168 & & & \\
\hline & & $\%$ & $37.5 \%$ & $16.7 \%$ & $45.8 \%$ & $100.0 \%$ & & & \\
\hline \multirow{8}{*}{$\begin{array}{l}\text { Multiple-choice } \\
\text { questions }\end{array}$} & Public School & $\mathrm{N}$ & 39 & 12 & 33 & 84 & 9.576 & 4 & $0.048 *$ \\
\hline & & $\%$ & $46.4 \%$ & $14.3 \%$ & $39.3 \%$ & $100.0 \%$ & & & \\
\hline & IB School & $\mathrm{N}$ & 11 & 1 & 18 & 30 & & & \\
\hline & & $\%$ & $36.7 \%$ & $3.3 \%$ & $60.0 \%$ & $100.0 \%$ & & & \\
\hline & Private School & $\mathrm{N}$ & 17 & 13 & 24 & 54 & & & \\
\hline & & $\%$ & $31.5 \%$ & $24.1 \%$ & $44.4 \%$ & $100.0 \%$ & & & \\
\hline & Total & $\mathrm{N}$ & 67 & 26 & 75 & 168 & & & \\
\hline & & $\%$ & $39.9 \%$ & $15.5 \%$ & $44.6 \%$ & $100.0 \%$ & & & \\
\hline \multirow{8}{*}{$\begin{array}{l}\text { Open-ended } \\
\text { tasks }\end{array}$} & Public School & $\mathrm{N}$ & 31 & 19 & 34 & 84 & 11.674 & 4 & $0.020 *$ \\
\hline & & $\%$ & $36.9 \%$ & $22.6 \%$ & $40.5 \%$ & $100.0 \%$ & & & \\
\hline & IB School & $\mathrm{N}$ & 4 & 3 & 23 & 30 & & & \\
\hline & & $\%$ & $13.3 \%$ & $10.0 \%$ & $76.7 \%$ & $100.0 \%$ & & & \\
\hline & Private School & $\mathrm{N}$ & 17 & 11 & 26 & 54 & & & \\
\hline & & $\%$ & $31.5 \%$ & $20.4 \%$ & $48.1 \%$ & $100.0 \%$ & & & \\
\hline & Total & $\mathrm{N}$ & 52 & 33 & 83 & 168 & & & \\
\hline & & $\%$ & $31.0 \%$ & $19.6 \%$ & $49.4 \%$ & $100.0 \%$ & & & \\
\hline \multirow[t]{8}{*}{ Portfolio } & Public School & $\mathrm{N}$ & 63 & 5 & 16 & 84 & 14.721 & 4 & $0.005^{*}$ \\
\hline & & $\%$ & $75.0 \%$ & $6.0 \%$ & $19.0 \%$ & $100.0 \%$ & & & \\
\hline & IB School & $\mathrm{N}$ & 15 & 2 & 13 & 30 & & & \\
\hline & & $\%$ & $50.0 \%$ & $6.7 \%$ & $43.3 \%$ & $100.0 \%$ & & & \\
\hline & Private School & $\mathrm{N}$ & 26 & 9 & 19 & 54 & & & \\
\hline & & $\%$ & $48.1 \%$ & $16.7 \%$ & $35.2 \%$ & $100.0 \%$ & & & \\
\hline & Total & $\mathrm{N}$ & 104 & 16 & 48 & 168 & & & \\
\hline & & $\%$ & $61.9 \%$ & $9.5 \%$ & $28.6 \%$ & $100.0 \%$ & & & \\
\hline
\end{tabular}


Merve Yıldııım Seheryeli, Selahattin Gelbal- Uluslararası Eğitim Programları ve Öğretim Çalışmaları Dergisi, 10(1), 2020, 221-260 Table 4. (Cont.)

\begin{tabular}{|c|c|c|c|c|c|c|c|c|c|}
\hline \multirow{2}{*}{\multicolumn{2}{|c|}{ Self-assessment Public School }} & $\mathrm{N}$ & 50 & 8 & 26 & 84 & 21.423 & 4 & $0.000^{*}$ \\
\hline & & $\%$ & $59.5 \%$ & $9.5 \%$ & $31.0 \%$ & $100.0 \%$ & & & \\
\hline \multirow{2}{*}{\multicolumn{2}{|c|}{ IB School }} & $\mathrm{N}$ & 5 & 4 & 21 & 30 & & & \\
\hline & & $\%$ & $16.7 \%$ & $13.3 \%$ & $70.0 \%$ & $100.0 \%$ & & & \\
\hline \multirow{2}{*}{\multicolumn{2}{|c|}{ Private School }} & $\mathrm{N}$ & 17 & 8 & 29 & 54 & & & \\
\hline & & $\%$ & $31.5 \%$ & $14.8 \%$ & $53.7 \%$ & $100.0 \%$ & & & \\
\hline \multirow{2}{*}{\multicolumn{2}{|c|}{ Total }} & $\mathrm{N}$ & 72 & 20 & 76 & 168 & & & \\
\hline & & $\%$ & $42.9 \%$ & $11.9 \%$ & $45.2 \%$ & $100.0 \%$ & & & \\
\hline \multirow{2}{*}{\multicolumn{2}{|c|}{ Peer assessment Public School }} & $\mathrm{N}$ & 56 & 11 & 17 & 84 & 23.775 & 4 & $0.000^{*}$ \\
\hline & & $\%$ & $66.7 \%$ & $13.1 \%$ & $20.2 \%$ & $100.0 \%$ & & & \\
\hline \multirow{2}{*}{\multicolumn{2}{|c|}{ IB School }} & $\mathrm{N}$ & 7 & 5 & 18 & 30 & & & \\
\hline & & $\%$ & $23.3 \%$ & $16.7 \%$ & $60.0 \%$ & $100.0 \%$ & & & \\
\hline \multirow{2}{*}{\multicolumn{2}{|c|}{ Private School }} & $\mathrm{N}$ & 20 & 8 & 26 & 54 & & & \\
\hline & & $\%$ & $37.0 \%$ & $14.8 \%$ & $48.1 \%$ & $100.0 \%$ & & & \\
\hline \multirow{2}{*}{\multicolumn{2}{|c|}{ Total }} & $\mathrm{N}$ & 83 & 24 & 61 & 168 & & & \\
\hline & & $\%$ & $49.4 \%$ & $14.3 \%$ & $36.3 \%$ & $100.0 \%$ & & & \\
\hline \multirow[t]{8}{*}{ Checklist } & \multirow[t]{2}{*}{ Public School } & $\mathrm{N}$ & 53 & 8 & 23 & 84 & 21.421 & 4 & $0.000^{*}$ \\
\hline & & $\%$ & $63.1 \%$ & $9.5 \%$ & $27.4 \%$ & $100.0 \%$ & & & \\
\hline & \multirow[t]{2}{*}{ IB School } & $\mathrm{N}$ & 6 & 4 & 20 & 30 & & & \\
\hline & & $\%$ & $20.0 \%$ & $13.3 \%$ & $66.7 \%$ & $100.0 \%$ & & & \\
\hline & \multirow[t]{2}{*}{ Private School } & $\mathrm{N}$ & 20 & 10 & 24 & 54 & & & \\
\hline & & $\%$ & $37.0 \%$ & $18.5 \%$ & $44.4 \%$ & $100.0 \%$ & & & \\
\hline & \multirow[t]{2}{*}{ Total } & $\mathrm{N}$ & 79 & 22 & 67 & 168 & & & \\
\hline & & $\%$ & $47.0 \%$ & $13.1 \%$ & $39.9 \%$ & $100.0 \%$ & & & \\
\hline & \multirow[t]{2}{*}{ Public School } & $\mathrm{N}$ & 53 & 9 & 22 & 84 & 19.807 & 4 & $0.001^{*}$ \\
\hline \multirow[t]{7}{*}{ Key(Rubric) } & & $\%$ & $63.1 \%$ & $10.7 \%$ & $26.2 \%$ & $100.0 \%$ & & & \\
\hline & \multirow[t]{2}{*}{ IB School } & $\mathrm{N}$ & 7 & 4 & 19 & 30 & & & \\
\hline & & $\%$ & $23.3 \%$ & $13.3 \%$ & $63.3 \%$ & $100.0 \%$ & & & \\
\hline & \multirow[t]{2}{*}{ Private School } & $\mathrm{N}$ & 20 & 11 & 23 & 54 & & & \\
\hline & & $\%$ & $37.0 \%$ & $20.4 \%$ & $42.6 \%$ & $100.0 \%$ & & & \\
\hline & \multirow[t]{2}{*}{ Total } & $\mathrm{N}$ & 80 & 24 & 64 & 168 & & & \\
\hline & & $\%$ & $47.6 \%$ & $14.3 \%$ & $38.1 \%$ & $100.0 \%$ & & & \\
\hline
\end{tabular}

${ }^{*} \mathrm{p}<0.05$.

The highest frequency of the teachers observing the students, and sharing the information they obtained with open-ended tasks with their students was indicated as at least once a week in all three school types. It was observed that the highest frequency of sharing the information they obtained with the portfolio with their students was at most maximum of once in a semester in all three school types. It was observed that the frequency of teachers to share the information they obtain with multiple choice questions, performance evaluation, self, and peer assessment, checklist, and grading key with their students was at most maximum of once in a semester in public schools, at least once a week in private, and IB schools. These differences between the rates were found to be significant at the 0.05 level. The highest value of these rates was observed in IB schools.

The highest frequency of teachers to share the information they obtained with feedback is stated at least once a week in all three school types. These differences between rates were not found statistically significant at the 0.05 level. There is no difference between school types. Therefore, the values related to these frequencies are not included in the table.

The results of the chi-square test of teachers working in public school, IB school, and private schools regarding the frequency of sharing the measurement and evaluation results with parents have been given in Table 5. 
Table 5.

Chi-Square Test Results Regarding the Frequency of Sharing Teachers' Measurement, and Evaluation Results with Parents According to the Type of School They Work At

\begin{tabular}{|c|c|c|c|c|c|c|c|c|c|}
\hline & & & $\begin{array}{l}\text { Maximum } \\
\text { once in a } \\
\text { semester }\end{array}$ & $\begin{array}{l}\text { Once in a } \\
\text { month }\end{array}$ & $\begin{array}{c}\text { At least } \\
\text { once a } \\
\text { week }\end{array}$ & Total & Chi-square & df & $\mathbf{p}$ \\
\hline \multirow[t]{8}{*}{ Feedback } & Public School & $\mathrm{N}$ & 38 & 18 & 28 & 84 & 10.582 & 4 & $0.032^{*}$ \\
\hline & & $\%$ & $45.2 \%$ & $21.4 \%$ & $33.3 \%$ & $100.0 \%$ & & & \\
\hline & IB School & $\mathrm{N}$ & 10 & 4 & 16 & 30 & & & \\
\hline & & $\%$ & $33.3 \%$ & $13.3 \%$ & $53.3 \%$ & $100.0 \%$ & & & \\
\hline & Private School & $\mathrm{N}$ & 12 & 17 & 25 & 54 & & & \\
\hline & & $\%$ & $22.2 \%$ & $31.5 \%$ & $46.3 \%$ & $100.0 \%$ & & & \\
\hline & Total & $\mathrm{N}$ & 60 & 39 & 69 & 168 & & & \\
\hline & & $\%$ & $35.7 \%$ & $23.2 \%$ & $41.1 \%$ & $100.0 \%$ & & & \\
\hline \multirow{8}{*}{$\begin{array}{l}\text { Multiple choice } \\
\text { questions }\end{array}$} & Public School & $\mathrm{N}$ & 51 & 15 & 18 & 84 & 12.285 & 4 & $0.015^{*}$ \\
\hline & & $\%$ & $60.7 \%$ & $17.9 \%$ & $21.4 \%$ & $100.0 \%$ & & & \\
\hline & IB School & $\mathrm{N}$ & 18 & 3 & 9 & 30 & & & \\
\hline & & $\%$ & $60.0 \%$ & $10.0 \%$ & $30.0 \%$ & $100.0 \%$ & & & \\
\hline & Private School & $\mathrm{N}$ & 18 & 13 & 23 & 54 & & & \\
\hline & & $\%$ & $33.3 \%$ & $24.1 \%$ & $42.6 \%$ & $100.0 \%$ & & & \\
\hline & Total & $\mathrm{N}$ & 87 & 31 & 50 & 168 & & & \\
\hline & & $\%$ & $51.8 \%$ & $18.5 \%$ & $29.8 \%$ & $100.0 \%$ & & & \\
\hline \multirow{8}{*}{$\begin{array}{l}\text { Open-ended } \\
\text { tasks }\end{array}$} & Public School & $\mathrm{N}$ & 50 & 14 & 20 & 84 & 11.31 & 4 & $0.023 *$ \\
\hline & & $\%$ & $59.5 \%$ & $16.7 \%$ & $23.8 \%$ & $100.0 \%$ & & & \\
\hline & IB School & $\mathrm{N}$ & 12 & 5 & 13 & 30 & & & \\
\hline & & $\%$ & $40.0 \%$ & $16.7 \%$ & $43.3 \%$ & $100.0 \%$ & & & \\
\hline & Private School & $\mathrm{N}$ & 19 & 17 & 18 & 54 & & & \\
\hline & & $\%$ & $35.2 \%$ & $31.5 \%$ & $33.3 \%$ & $100.0 \%$ & & & \\
\hline & Total & $\mathrm{N}$ & 81 & 36 & 51 & 168 & & & \\
\hline & & $\%$ & $48.2 \%$ & $21.4 \%$ & $30.4 \%$ & $100.0 \%$ & & & \\
\hline \multirow[t]{8}{*}{ Portfolio } & Public School & $\mathrm{N}$ & 65 & 6 & 13 & 84 & 15.074 & 4 & $0.005^{*}$ \\
\hline & & $\%$ & $77.4 \%$ & $7.1 \%$ & $15.5 \%$ & $100.0 \%$ & & & \\
\hline & IB School & $\mathrm{N}$ & 18 & 4 & 8 & 30 & & & \\
\hline & & $\%$ & $60.0 \%$ & $13.3 \%$ & $26.7 \%$ & $100.0 \%$ & & & \\
\hline & Private School & $\mathrm{N}$ & 27 & 15 & 12 & 54 & & & \\
\hline & & $\%$ & $50.0 \%$ & $27.8 \%$ & $22.2 \%$ & $100.0 \%$ & & & \\
\hline & Total & $\mathrm{N}$ & 110 & 25 & 33 & 168 & & & \\
\hline & & $\%$ & $65.5 \%$ & $14.9 \%$ & $19.6 \%$ & $100.0 \%$ & & & \\
\hline \multirow[t]{8}{*}{ Self-assessment } & Public School & $\mathrm{N}$ & 58 & 11 & 15 & 84 & 14.939 & 4 & $0.005^{*}$ \\
\hline & & $\%$ & $69.0 \%$ & $13.1 \%$ & $17.9 \%$ & $100.0 \%$ & & & \\
\hline & IB School & $\mathrm{N}$ & 13 & 4 & 13 & 30 & & & \\
\hline & & $\%$ & $43.3 \%$ & $13.3 \%$ & $43.3 \%$ & $100.0 \%$ & & & \\
\hline & Private School & $\mathrm{N}$ & 22 & 13 & 19 & 54 & & & \\
\hline & & $\%$ & $40.7 \%$ & $24.1 \%$ & $35.2 \%$ & $100.0 \%$ & & & \\
\hline & Total & $\mathrm{N}$ & 93 & 28 & 47 & 168 & & & \\
\hline & & $\%$ & $55.4 \%$ & $16.7 \%$ & $28.0 \%$ & $100.0 \%$ & & & \\
\hline \multirow[t]{5}{*}{ Peer assessment } & t Public School & $\mathrm{N}$ & 57 & 15 & 12 & 84 & 11.47 & 4 & $0.022^{*}$ \\
\hline & & $\%$ & $67.9 \%$ & $17.9 \%$ & $14.3 \%$ & $100.0 \%$ & & & \\
\hline & IB School & $\mathrm{N}$ & 18 & 4 & 8 & 30 & & & \\
\hline & & $\%$ & $60.0 \%$ & $13.3 \%$ & $26.7 \%$ & $100.0 \%$ & & & \\
\hline & Private School & $\mathrm{N}$ & 22 & 16 & 16 & 54 & & & \\
\hline
\end{tabular}


Merve Yıldııım Seheryeli, Selahattin Gelbal- Uluslararası Eğitim Programları ve Öğretim Çalışmaları Dergisi, 10(1), 2020, 221-260 Table 5 (Cont.)

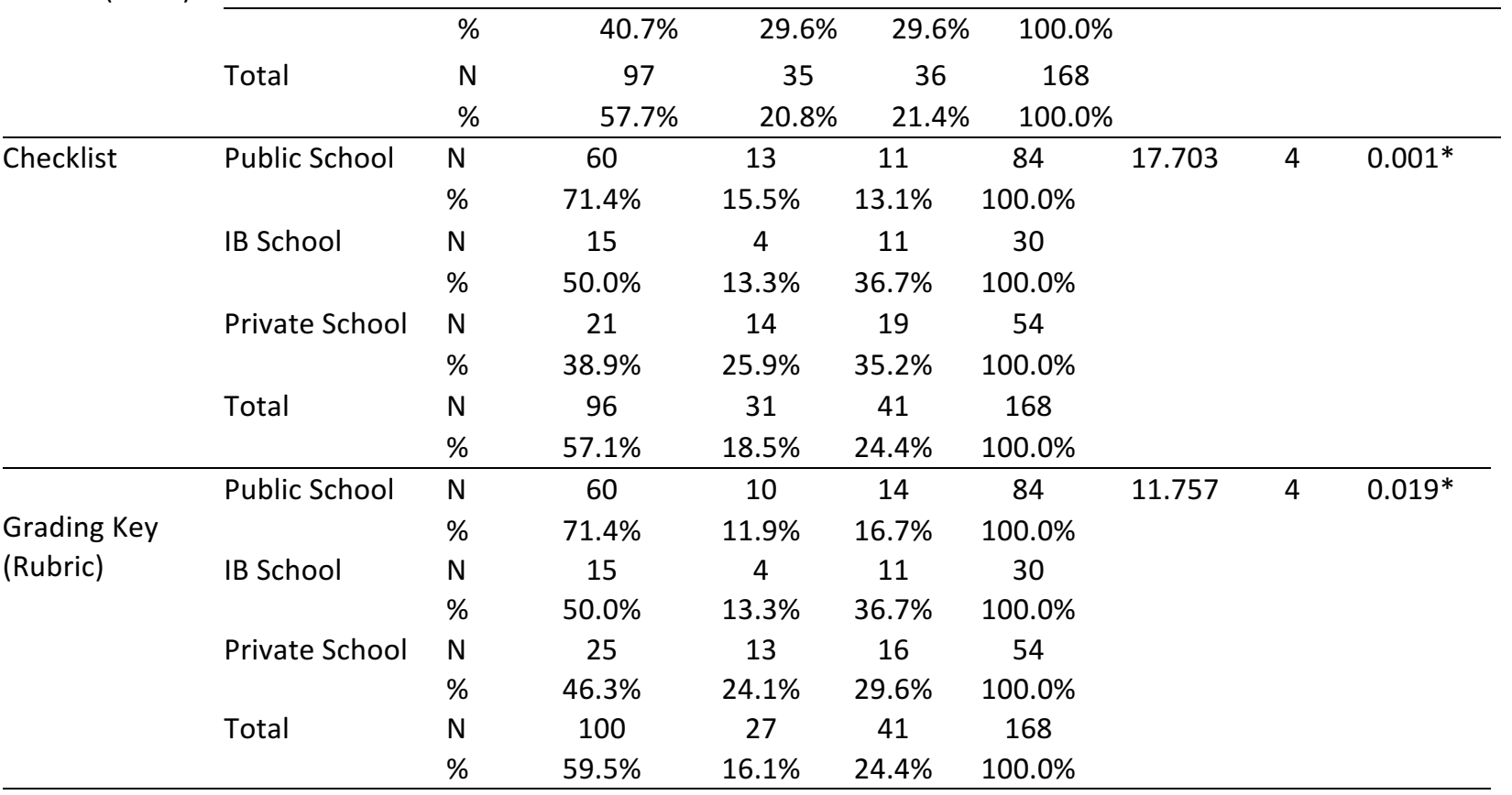

${ }^{*} \mathrm{p}<0.05$.

As can be seen at the table the frequency of teachers' sharing the information obtained by observing the students with their parents was at most once in the public schools, and at least once a week in private and IB schools. It was seen that the frequency of sharing the information they obtained through performance evaluation with their parents was at most once in the public schools, once in IB schools, and at least once a week in private schools. These differences between ratios were not found statistically significant at the 0.05 level. Therefore, the values related to these frequencies are not included in the table. There is no difference between the frequency of sharing the information by observing students and evaluating performance with parents.

It was seen that the highest frequency of teachers' sharing the information with their parents that were collected through feedback was maximum of once in a semester in public schools, and at least once a week in private and IB schools. The frequency of sharing the information through multiple choice questions was at most maximum once in a semester in public and IB schools, and at least once in Private schools. The frequency of sharing the information with their parents that they obtain through open-ended tasks was at most once in public schools, and private schools, at least once a week in IB schools; The highest frequency of sharing the information with their parents that they obtain with the portfolio, self, and peer assessment, checklist, and grading key was maximum of once in a semester in all three school types. These differences between the rates were found statistically significant at the 0.05 level. The frequency of information sharing with parents varies between schools. While the frequency of sharing with parents in IB schools, and private schools was at least once a week in general, it was generally observed at most maximum once in a semester in public schools. The highest value of these rates was observed in IB schools.

\section{Discussion, Conclusion and Implications}

In this research, the measurement and evaluation studies of the teachers working at MEB public, private, and IB schools in Turkey and their opinions on this subject were examined. The findings of the research mainly included the concepts that came to their minds of teachers firstly when measurement and evaluation were mentioned. These concepts were grouped under "Basic Concepts", "Statistics", "What Do We Assess?", "Why do We Assess?" and "How Do We Assess?" titles. 
Merve Yıldırım Seheryeli, Selahattin Gelbal- Uluslararası Eğitim Programları ve Öğretim Çalışmaları Dergisi, 10(1), 2020, 221-260

Fairness and holistic evaluation are the concepts were seen in only one school under the title of "Basic Concepts". The holistic evaluation concept was more prominent in IB schools, and was considered as a more suitable method for making decisions about students, especially in the transition to European universities that accept students without an entrance exam (IBO, 2018d). Due to the frequent use of exams and tests in public schools and private schools for evaluation, decision making based on the rank and score of the students was more common (Gelbal \& Kelecioğlu, 2007). Therefore, it was thought that the concept of justice does not stand out since the concept of justice differs, and the evaluation for individual development in IB schools does not aim to rank.

It was seen that the prominent concepts of the "Statistics" title were similar in IB and private schools. This can be a result of having a school coordinator or measurement and evaluation expert in private and IB schools that enable the teachers to evaluate their questions.

Process evaluation studies were more prominent in IB schools than in other schools because studies were carried out to enable mastery learning, and to monitor and develop the students concerning their individual differences (IBO, 2018d). Accordingly, the prominent concepts as an answer to "What do we assess?" question in IB schools were expected to be process, outcome, and skill. Consequently, individualization of the curriculum would contribute to mastery learning not only when special education is needed but also when it has a flexible structure that can be differentiated according to the need of each student (Ayyıldız \& Üzümcü, 2016).

It has been seen that the most prominent concept for the answer to "Why do we assess?" question is feedback in all school types. Reflective thinking, differentiation, needs assessment, planning, and reporting was not only performed to assess the students, but was also seen as a means to support learning, and performed for evaluation at IB schools. This finding was supported by the study results reported by Toe et al. (2015), and by the study results of Guler Yaltirik (2011) with the idea that teachers regard the measurement, and evaluation as the strength of IB.

It was seen that the answer to the "How do we assess?" question, the measurement, and evaluation tools used in public schools focused on the preparation of exams, and in private schools, both exam and development of the student is considered. It has been observed that tools are differentiated according to the needs of the students to serve the IB learner profile based on inquiry, and skill development (IBO, 2018d). This finding showed similarities with the study results reported by Toe et al. (2015).

The second research question about whether the teachers have a measurement and evaluation system that they use at their schools and if so how they implement this system at their the classrooms. The measurement and evaluation system planned to be used at schools by teachers, and education practitioners were included in the MEB curriculum, and they were free to implement these in the classroom in accordance with their competencies; but its implication was emphasized(MEB, 2013; 2018; 2019). However, in IB schools, measurement, and evaluation practices required to be applied, recorded, and reported (IBO, 2018d). 48\% of the teachers in public schools, $83 \%$ of the private school teachers, and $93 \%$ of the IB school teachers stated that they applied a measurement and evaluation system. It was seen that the rate in public schools was quite less than the other school types. The studies of Guler, and Yaltirik (2011), and Toe et al. (2015) indicated the strength of IB as the regular evaluation of their measurement and evaluation practices by IBO officials. This requirement varied in private schools in line with the school policies. Therefore, it could be said that an inspection mechanism is needed in order to enable the teachers to apply and adopt the measurement and evaluation practices.

The teachers with a measurement and evaluation system in their schools, the ones mentioning about the activities carried out to apply this system was $69 \%$ of all participants. Participant expressions were grouped under "Summative", "Reinforcement of Learning", "Contributing to The Quality of The System", "Evaluation Practices" and " Documenting of Collected information" titles. 
Merve Yıldırım Seheryeli, Selahattin Gelbal- Uluslararası Eğitim Programları ve Öğretim Çalışmaları Dergisi, 10(1), 2020, 221-260

It could be said that the teachers who stated having "Summative" practices, the studies which varied according to the schools were the assessment of skills, writing questions in line with the outcome- taxonomy, new generation questions. It could be stated that this differentiation was mainly a result of exam-focused preparation of students in public and private schools. These findings obtained for public schools also match up with the findings of other studies in the literature (Arda, 2009; Gök \& Şahin, 2009; Yapıcı \& Demirdelen, 2007). It was seen that the cognitive level of the students' learning or their deficiencies were determined by writing questions based on the outcome, and taxonomy in private schools.

It could be said that the teachers who stated having "Reinforcement of Learning" practices, the studies which vary according to the schools were inquiry studies. Within this context, the learning reinforcement studies were limited to the traditional level in public and private schools, and they focused on the reinforcement of skills in IB schools. This situation also indicates that IB schools adopted the philosophy specified by IBO (2012; 2018b; 2018c; 2018d) at the school level. It can be said that, especially in IB schools (Kauffman, 2005), the national-international perspectives gained by teachers in the process of developing students' learning through inquiry-based studies diversify teacher competencies.

It was seen that for the teachers who stated that they "Contributed to The Quality of The System", the most prominent studies were acting fairly in public schools; considering individual differences, and group cooperation in private schools, and inter-disciplinary working, and group cooperations, and setting the criteria with the students or informing the students about the criteria in IB schools. It was thought that this matched up with the expectations of IBO (2012) and that all educational situations in IB schools were prepared in a learner-centered manner to serve the themes in cooperation with other groups. When the practices of teachers, especially in public, and private schools, were examined, it was seen that they tend towards studies such as fairness, R\&D team, butterfly system, or Web 2.0 tools. In this case, it could be said that teachers need more effective support in order to contribute to the quality of the system.

The most prominent studies of teachers who state that they do "Evaluation" studies were feedback and performance evaluation in public schools. While the most prominent studies were the feedback and process-oriented evaluation in private schools, IB schools have grading key and process-oriented evaluation. In this case, it can be said that process-oriented studies are carried out in the evaluation studies in all three school types.

The key words collected according to schools under the "Documenting" title were analysis results, improvement reports, and education planning. The teachers who stated that they had a measurement and evaluation system in their schools, and document the data to actualize this system stated two opinions in public schools, one opinion in private schools, and ten opinions in IB schools.

Even though studies like analysis and reporting were mentioned only once by the teachers who stated having "Documenting of Collected information", studies, planning, and education planning studies have become prominent, especially in IB schools. The reason for this could be indicated as the requirement of evaluation (Güler \& Yaltırık, 2011; Toe et al., 2015) to continue IB accreditation. Therefore, it was seen that program evaluation practices, and particularly systematic tracking of their application, required to be given importance. Additionally, it was thought that in-service training studies would help to eliminate the differences between these schools, especially when focused on education planning according to the assessment results.

In the findings concerning the third research question, the frequencies of teachers' using ten given measurement and evaluation techniques stated, documenting of collected information, and sharing this information with students and parents are compared.

In the studies that Gelbal and Kelecioğlu (2007) analyzed the teachers' opinions, they stated that teachers mostly prefer traditional methods, and use the methods for self-assessment of students less 
Merve Yıldırım Seheryeli, Selahattin Gelbal- Uluslararası Eğitim Programları ve Öğretim Çalışmaları Dergisi, 10(1), 2020, 221-260 frequently. This contradicts with the findings that when the frequency of use of tools and methods were examined, frequency of observation of the students, feedback, performance evaluation (presentation, discussion, role play, etc), multiple-choice questions, open-ended tasks, portfolio use did not differ. As a result of this, it could be said that teachers currently have started to see the complementary measurement and evaluation approaches as a part of the education process.

When the frequency of teachers' documenting collected information was analyzed, it was seen that documenting the frequency of multiple-choice questions, and open-ended tasks did not differ between schools; The frequency of observing students, feedback, performance evaluation (presentation, discussion, role play, etc.), portfolio, self, and peer assessment, checklist, grading key is found to be higher in IB schools than in other schools. This finding matched up with the opinions mentioned in the report prepared by Toe et al. (2015), stating that teachers use different assessment tools together, and record the information they obtained by adopting the concept of developmental continuity.

When the frequency of sharing the information collected by the teachers with the students was analyzed, it was seen that there was a difference in all tools and methods except feedback, and their frequency was higher in IB schools than in other schools. It could be said that teachers, especially the ones working in private and public schools, used the evaluation to grade or review their educational status. However, students needed to be informed about these results in order to guide their learning. When the frequency of sharing the information with parents was analyzed, there was a difference in all tools, and methods except for observing students, and evaluating performance; the frequency of multiple-choice questions and peer assessment was observed higher in private schools, and the frequency of other tools and methods was higher in IB schools. It draws attention that while the frequency of giving feedback to students does not differ, the frequency of giving feedback to the data differs. Toe et al. (2015) emphasized the importance of effective feedback rather than personally praising the students to themselves and their parents.

The findings revealed that in-class applications of teachers in public, private, and IB schools differ in line with the school goals. Consequently, the use of curricula in which the expectations of MEB or any school from "measurement, and evaluation are stated clearly in writing, and sample applications, and studies to implement are given with all details, will ensure making a qualified measurement, and evaluation by enabling teachers to adapt their work. Also, it can be suggested to have a measurement and evaluation specialist and a program development expert at schools in order to provide support for the development of student learning with measurement, and evaluation, and feedback that is needed by teachers. In this way, the necessary support to assess, and develop high-order thinking skills by considering the result, and process together, and with the individual differences. Similarly, when the schools were inspected, the frequency of using measurement and evaluation tools and methods increases. Accountability would be provided by establishing external inspecting mechanisms, and each school will be inspected. The reasons for these findings should be studied in more detail. Finally, studies similar to the ones in IB schools could be carried out in private and public schools, and the effectiveness of these studies could be evaluated by action research. 


\section{TÜRKÇE SÜRÜM}

\section{Giriş}

Her ülkenin eğitim sistemi, eğitim programının özellikleri doğrultusunda işlerlik kazanır. Bir eğitim programı tasarlanırken iki temel yaklaşımdan bahsedilir. Birincisinde eğitim programları bir sistem olarak düşünülerek ortak amaçlara hizmet eden ögelerin karmaşık bir bütünü olarak ele alınır (Erden, 1998). Eğitimin amaçları konu alanı, toplum ve öğrenci özellikleri kapsamında önceden belirlenip incelenebilir. İçerik, yöntem ve öğrenme ortamları uzman görüşleri ve araştırmalar çerçevesinde belirlenir. Değerlendirme, amaca ulaşma derecesi anlamına gelir (Demirel, 2012; Ertürk, 2013). Değerlendirme sonucu elde edilen bilgiler doğrultusunda program ögeleri gözden geçirilebilir (Demirel, 2012; Erden, 1998). İkinci yaklaşımda ise öğrenci ihtiyaçları ve süreçüründen daha ön planda tutulur. Amaç ve süreç öğretimin yapıldığı koşullara göre sürekli değişim içindedir bu nedenle önceden bilinmesi mümkün değildir (Erden, 1998). Programa ilişkin alınacak kararlarda ise uzman görüşleri yerine öğrenci ve öğretmen görüşleri, tercihleri, algıları daha ön plandadır (Demirel, 2012; Erden, 1998). Dolayısı ile hangi tasarım yaklaşımının benimsendiği; hedeflerin, eğitim durumlarının, içeriğin, ölçme ve değerlendirme yöntemlerinin de farklılaşmasını sağlayacaktır.

Türkiye'de 1968 yılında toplu olarak geliştirilen ilkokul programından sonra Millî Eğitim Bakanlığı (MEB) tarafından yine toplu olarak 2004-2005 yılları arasında yeni ilköğretim programı geliştirilmiş, programın temelinde yapılandırmacı yaklaşım benimsenmiştir (Yüksel \& Sağlam, 2014). Bu yaklaşıma göre öğretmen bilgiyi doğrudan aktaran değil, bilgiye giden yolda öğrencilerine rehberlik eden konumundadır (Erdoğan, Kayır, Kaplan, Ünal \& Akbunar, 2015; Senemoğlu, 2012). 2013 ve 2018 yıllarında geliştirilen programlarda da aynı yaklaşım temel alınmaya devam edilmiştir. 2018 yılından beri uygulamada olan tüm öğretim programlarında ölçme ve değerlendirme sürecinin her birey için standart olmasının beklenmesinin gerçekçi olmadığı, çeşitlilik ve esnekliğe dikkat edilmesi gerektiği, kullanılacak yöntem ve tekniklerin öğretmenlerden ve eğitim uygulayıcılarından özgünlük ve yaratıcılık ile beklendiği belirtilmiştir. Bunlara ek olarak kazanımların ve açıklamaların çerçevesinde sadece sonucun değil sürecin de değerlendirildiğinden, kullanılacak araç ve yöntemlerin teknik ve akademik standartlara uyması gerektiğinden, bireysel farklılıkların baz alındığından, sadece bilişsel değil duyuşsal ve psikomotor alanların da ölçülmesinin gereğinden, ölçme ve değerlendirme süreçlerinde öğretmen ve öğrencinin birlikte aktif olmasının öneminden söz edilmiştir (MEB, 2013; 2018; 2019). MEB 2023 Eğitim Vizyonu'nda ise bu beklentilerin "yeterlik temelli ölçme ve değerlendirme sisteminin kurulması", "sosyal, kültürel, sportif faaliyetlerin izlenmesi", "e-portfolyo ile öğrencilerin okul öncesinden üniversiteye kadar izlenmesi", "ölçme ve değerlendirme yöntemlerinin etkinleştirilmesi", "kademeler arasındaki geçiş sınavlarının eğitim sistemi üzerindeki baskısının azaltılması" gibi hedeflere evirildiği görülmektedir. Bahsedilen tüm uygulamalar devlet okullarından beklendiği gibi MEB Özel Öğretim Kurumlar Yönetmeliğince (2012) denetlenen tüm özel okullardan da beklenmektedir.

Alanyazında, paydaşların eğitim durumlarına ile ölçme ve değerlendirmeye ilişkin görüşlerinin alındığı çalışmalar bulunurken okullar ve öğretmenler tarafından MEB beklentilerinin ne derece karşılandığına ilişkin çalışmalara daha az rastlanmaktadır. Gelbal ve Kelecioğlu'nun (2007) yapılandırmacı yaklaşımın benimsendiği sınıflarda kullanılan ölçme ve değerlendirme yöntemlerine yönelik öğretmen görüşlerini inceledikleri araştırmalarında öğretmenlerin öğrenci başarısını belirlemede geleneksel yöntemleri tercih ettikleri, kendilerini yeterli gördükleri yöntem ve teknikleri daha sık kullandıkları, öğrenci değerlendirmesine yönelik yöntemleri en az sıklıkla kullandıkları bulgusuna ulaşmışlardır. Yöntemleri kullanmada sorunla karşılaşmadıklarını belirten öğretmenler sınıftaki kişi sayısının fazlalığı, zaman yetersizliği ve araçların hazırlanma zorluğundan da bahsetmişlerdir. Arda'nın (2009) 2005 öğretim programı için sınıf öğretmenlerinin yeterlikleri ile birlikte ölçme ve değerlendirmeye ilişkin görüşlerini incelediği çalışmasında ise öğretmenler, yenilenen programa göre eğitim almamış olmaktan kaynaklanan sıkıntılarından, ölçme ve değerlendirme kurallarına zaman zaman uyduklarından, başarısızlık sebebi olarak en fazla öğrencileri en az ölçme 
Merve Yıldırım Seheryeli, Selahattin Gelbal- Uluslararası Eğitim Programları ve Öğretim Çalışmaları Dergisi, 10(1), 2020, 221-260 araçlarını sorumlu tuttuklarından bahsetmişlerdir. Bunun yanında karşılaştıkları sorunların fiziksel ortamdan, sosyal çevre ve veli profilinden, ölçme ve değerlendirmenin ayrıntılı karmaşık ve vakit alıcı olmasından, programın kendisinden kaynaklandığını belirtmişlerdir. Gök ve Şahin (2009) çalışmalarını yalnız 4 ve 5. sınıf öğretmenleri ile yürütmüşlerdir. Öğretmenler geleneksel değerlendirme yöntemlerini kullanmada kendilerini yeterli gördüklerini, yeni değerlendirme çalışmalarını geleneksel değerlendirme çalışmalarına tercih etmediklerini, yeni değerlendirme çalışmalarını kullanma, araç hazırlama, puanlama gibi konularda desteğe intiyaçları olduğunu, kullandıkları yeni yaklaşımları karne notu olarak yansıtmada zorlandıklarını belirtmişlerdir. Bu bulgularla benzer sonuçlar Yapıcı ve Demirdelen (2007) tarafından da elde edilmiş̧ir.

Ülkemizde son istatistiklere göre (MEB, 2019) tüm kademelerle birlikte 54036 resmi, 12809 özel ve 4 açık öğretim okulu örgün eğitim vermektedir. Bu okulların her birinde aynı program temel alınsa bile yapılan uygulamalar öğretmenlerin ve uygulayıcıların niteliklerine, kurumların hedeflerine göre farklılaşmaktadır. Bu farklılıklar devlet okullarında öğretmenlerin nitelikleri ile daha ilişkili iken özel okullarda kurum politikalarına hizmet edecek şekilde çalışmalar yapılmaktadır. Özel okulların tercih edilme sıklıklarını, veli ve öğrenci memnuniyetlerini artırmak için devlet okullarından farklı çalışmalara ev sahipliği yaptığı görülmektedir. Bu çalışmalar spor faaliyetleri ve sanatsal faaliyetler olabildiği gibi yine MEB tarafından onaylanmıs kendi programlarını kullanmaları, STEM (Science, Technology, Engineering ve Math) etkinlikleri ile programlarını farklılaştırmaları ya da Uluslararası Bakalorya Organizasyonu (IBO) gibi yurt dışındaki kurumlarca akreditasyon almalarıdır. Bu çalışmada devlet ve özel okullarla birlikte Uluslararası Bakalorya (IB) okulları da araştırmaya dâhil edilmiştir. Ülkemizdeki okullardan yalnız 79'u (2 devlet okulu, 77 özel okul) IB okulu olarak akreditasyon almıştır (IBO, t.y.).

Uluslararası Bakalorya Organizasyonu (IBO) kültürlerarası ve evrensel bir eğitim sistemini hayata geçirmek amacıyla İsviçre'nin Cenevre kentinde kurulmuştur. Kuruluş amacı, ortak bir eğitim sistemi sayesinde diplomatlar ve uluslararası işlerde çalışan insanların çocuklarının coğrafi ve kültürel hareketliliğinin akademik gelişimlerini engellemesinin önüne geçmektir (Ateş, 2011; IBO, 2012). IBO, ilk yıllar programı (PYP), orta yıllar programı (MYP), diploma programı (DP) ve mesleki kariyer programı (CP) olmak üzere yaşam boyu öğrenenleri desteklemeyi sürdürmektedir. IBO, disiplinler üstü bir yaklaşımla yedi temaya (Kim olduğumuz, Bulunduğumuz yer ve zaman, Kendimizi ifade etme yollarımız, Kendimizi nasıl organize ederiz, Gezegeni paylaşmak) hizmet edecek şekilde önceden planlanan eğitim durumları sayesinde öğrenen merkezli, sorgulamayı ve araştırmayı temel alan, ölçme ve değerlendirme sayesinde akademik dürüstlüğü sağlamayı, farklılıklara hoşgörü ile yaklaşan bireyler yetiştirmeyi amaçlamaktadır (IBO, 2012). Bu amaçları gerçekleştirebilmek için "IB öğrenen profili" başlığında öğrencilerden beklenen beceriler belirlenmiştir: Araştıran-sorgulayan, bilgili, düşünen, iletişim kuran, ilkeli, açık görüşlü, duyarlı, riski göze alan, dengeli, yansıtıcı düşünen (IBO, 2018a; IBO, 2018b).

IB ölçme ve değerlendirilmesinde ise sonuç ve süreç birlikte değerlendirilirken öğrencilerin değerlendirme yapabilmeleri için öğretmen tarafından desteklenmesi ön plandadır. Öğretmenlerden ölçme ve değerlendirmeyi üç aşamada gerçekleştirmeleri beklenmektedir: Değerleme (assessing), kaydetme ve raporlama. Değerlemede süreç ve sonuç dâhil olmak üzere her öğrencinin bireysel farklılıklarını baz alarak tüm değerlendirme araç ve yöntemlerinin kullanılabileceği özellikle geri bildirimlerle öğrenmenin desteklenmesi gerektiği vurgulanmaktadır (IBO, 2018c). Öğrencilerin tüm değerlendirme süreçlerinden, kriterlerinden ve elde edilen sonuçlardan haberdar edilmesinin ötesinde sürece dâhil edilmesinden bahsedilmektedir. Kaydetme aşamasında elde edilen bilgilerin gözlem ya da öğretmen kanısı olarak kalmaması için araçlarla, anekdotlarda, öğrenci yansıtmalarıyla kayıt altına alınmasının, öğrenci gelişiminin kanıtlarının toplanmasının önemi belirtilmektedir. Raporlama aşamasında ise öğrencinin öğrenme sürecine katkıda bulunacak ya da bulunmuş tüm paydaşlara sözlü ve yazılı, kapsamlı, tarafsız ve adil hazırlanmış raporlar ya da paylaşımlar (öğretmen-öğrenci, öğretmenveli, öğretmen-öğrenci-veli katılımlı) yapılması beklenmektedir. Bu aşamalardan önce ise okulun kendine ait bir ölçme ve değerlendirme politikasının olmasını, bu politika çerçevesinde yapılacak uygulamaların tüm paydaşların süreçlere katılarak gerçekleştirilmesi gerekmektedir. IBO tarafından 
Merve Yıldırım Seheryeli, Selahattin Gelbal- Uluslararası Eğitim Programları ve Öğretim Çalışmaları Dergisi, 10(1), 2020, 221-260 düzenli olarak gerçekleştirilen denetlemeler tüm okulların sistemli bir şekilde ölçme ve değerlendirme faaliyetlerini yürütmelerini de zorunlu kılmaktadır (Büyükgenç, 2014; IBO, 2018d; IBO, 2012).

IBO tarafından akreditasyon süreci tamamlanan özel okulların diğer okullarla karşılaştıııldığı çalışmalarda aile içi iletişimler ile sosyal beceriler (Özeke Kocabaş \& Akkök, 2016), IB okulu olmaya geçişte yöneticilerin yaşadıkları zorluklar (Oraz, 2019) gibi konulara rastlanmıştır. IB ilk yıllar programı ile ilgili çalışmalarda ise programa ilişkin öğretmen görüşleri (Güler \& Yaltırık, 2011), öğretmenlerin uygulamaları, değerleri ve inançları (Twigg, 2010) incelenmiştir. IB diploma programı ile ilgili çalışmalarda ise farklı ülkelerdeki okulların değerler eğitimi ile ilgili öğretmen görüşleri (Şanver, 2016), öğrencilerin okuma alışkanlıkları ve okumaya yönelik tutumları (Keleş, 2013), programın intihal ile ilgili kavram yanılgılarına etkisi (Baysen, Baysen \& Çakmak, 2017), öğrencilerin öğrenme iklimi ile ilgili algıları (Bora, 2010), bu programında uygulanan coğrafya dersi (Ateş, 2011), uygulanmasındaki farklılıklar (Kauffman, 2005), mezun öğrencilerin görüşleri (Büyükgenç, 2014) gibi konulara yer verilmiş̧ir. Tüm çalışmalarda IB programının ilgilenilen özelliklere pozitif etkisinin olduğu, diğer okullarla karşılaştırıldığında IB programının güçlü yönlerinin fazla olduğu söylenmektedir. Bu çalışmalara ek olarak Toe et al. (2015) tarafından sekiz farklı okuldaki IB ilk yıllar programında yürütülen bir projede yapılan eylem araştırmasında okulların değerlendirme politikalarında ve değerlendirme uygulamalarında eğitimsel değerlendirmenin amacını nasıl tanımladıkları araştırılmıştır. Araştırma sonucunda öğretmenlerin biçimlendirici ve düzey belirleyici değerlendirmeyi birlikte kullandığı, geniş ölçekli testlerin sisteme dâhil edilmesi konusunda görüş ayrılıkları olsa da tümel yaklaşımın hâkim olduğu görülmüştür. Öğretmenlerin bireysel farklılıkları temel alarak öğrencilerinin düzeylerini belirleme, öğrenmelerini geliştirme ve değerlendirmeyi öğrenmeleri konularında planlamalar yaptıkları, farklı değerlendirme araçlarını birlikte kullandıklarını belirtmişlerdir. Bunlarla birlikte gelişimsel süreklilik kavramın benimseyerek elde ettikleri bilgileri kayıt altına aldıklarını, kişisel övgü yerine etkili geribildirimin önemini vurgulamışlardır. Benzer sonuçlar Güler ve Yaltırık (2011) ve Oraz (2019) tarafından da elde edilmiştir.

Tüm bu açıklamalar doğrultusunda bu çalışmada Türkiye'deki IB okullarında ve MEB'e bağlı özel ve devlet okullarındaki öğretmenlerin ölçme ve değerlendirme çalışmaları ve bu konudaki görüşleri konu edinilmiştir. Önemli gerekçelerden biri Uluslararası Bakalorya uygulanan okullardan mezun olan öğrencilerin üniversiteye geçişte farklı yöntemlerin (sınavsız geçiş, üniversitenin kriterlerini sağlama vb.) kullanıldığı Avrupa ülkelerindeki üniversitelere başvuru yapabilmesidir. Bu nedenle ülkemizdeki eğitim sürecine bir alternatif olması nedeniyle ölçme ve değerlendirme süreçlerinin incelenmesine de intiyaç duyulmaktadır. Bu sayede okul türlerine göre yapılan çalışmaların benzer ve farklı yönleri ile öğretmenlerin görüşlerinin neler olduğu belirlenebilecektir. Bunun yanında tüm okul türleri için öğretim programlarında önerilen ölçme ve değerlendirme yaklaşımlarının öğretmenler tarafından ne sıklıkla uygulandığına ilişkin de bilgi elde edilebilecektir. Bunlara ek olarak bir okuldaki üstün yönlerin diğer okul türlerindeki eğitimciler tarafından kullanılmasının, benzer yöntemlerin tüm okul türlerinde kullanılarak okullar arasındaki farkların azaltılmasına katkı sağlayabileceği düşünülmektedir. Bu katkının bir sonucu olarak özellikle bu farklar azaldığında değerlendirme sonucu elde edilen ölçümlerin yanlılık içermesi sorunu da azaltılabilecektir. Dolayısı ile ölçme ve değerlendirme alanında sıklıkla tartışılan "test adaleti", "yanlılık", "değiş̧en madde fonksiyonu" ve "ölçme değişmezliği" gibi konulara da ön bilgi sağlanabileceği düşünülmektedir.

\section{Araştırmanın Amacı}

Bu araştırmanın amacı devlet okullarında, özel okullarda ve Uluslararası Bakalorya (IB) okullarında görev yapan öğretmenlerin ölçme ve değerlendirme çalışmalarına bakış açıları ile ölçme ve değerlendirme yöntem ve tekniklerini kullanma, elde ettikleri bilgileri kayıt altına alma ve öğrencivelilere geribildirim verme sıklıklarını incelemektir. Bu amaç doğrultusunda aşağıdaki alt problemlere yanıt aranmıştır.

4. Devlet okulu, özel okul ve IB okullarında görev yapan öğretmenler "ölçme ve değerlendirme”yi hangi kavramlarla ilişkilendirmektedir? 
Merve Yıldırım Seheryeli, Selahattin Gelbal- Uluslararası Eğitim Programları ve Öğretim Çalışmaları Dergisi, 10(1), 2020, 221-260

5. Öğretmenlerin bir ölçme ve değerlendirme sistemine tabi oldukları düşünceleri okul türüne göre anlamlı bir fark göstermekte midir? Sisteme tabi olduğunu düşünen öğretmenler bu sisteme nasıl katkı sağlamaktadır?

6. Devlet okulu, özel okul ve IB okullarında görev yapan öğretmenlerin;

a) farklı ölçme ve değerlendirme tekniklerini kullanma,

b) ölçme ve değerlendirme sonucunda elde ettikleri bilgileri,

i. kayıt altına alma

ii. öğrencilerle paylaşma

iii. velilerle paylaşma

sıklıkları arasında anlamlı bir fark var mıdır?

\section{Yöntem}

Bu araştırmada, farklı okul türlerinde görev yapan öğretmenlerin ölçme ve değerlendirme çalışmalarına bakış açıları ile ölçme araçlarını kullanım, elde ettikleri bilgilerin kayıt altına alma ve öğrenci-velilere yaptıkları geribildirim sıklıkları incelenmiştir. Bu nedenle çalışmada mevcut bir durumun, bireylerin ya da nesnelerin kendi koşulları içinde değiştirilmeden olduğu gibi tanımlanması ve aktarılması amaçlandığından (Büyüköztürk, Çakmak, Akgün, Karadeniz \& Demirel, 2019) tarama modelinde bir araştırma yürütülmüştür.

\section{Evren ve örneklem}

Bu araştırmanın evrenini 2019-2020 eğitim ve öğretim yılında Türkiye'deki devlet okulları, IB aday/IB okulları ve özel okullarda görev yapan öğretmenler oluşturmaktadır. Öğretmenlerin görev yaptıkları devlet okulları sayısı 54036, özel okul sayısı 12809 (MEB, 2019) ve IB okulu sayısı 77'dir. Tüm okulların \%80.8'i devlet, \%19.1'i özel, \%0.1'i IB okuludur (IBO, t.y.).

Araştırmanın örneklemi zaman, para ve işgücü açısından oluşan sınırlııkları gidermek için (Büyüköztürk et al., 2019) seçkisiz olmayan örnekleme yöntemlerinden biri olan uygun örnekleme ile belirlenmiştir. Araştırmanın tasarı aşamasında daha fazla öğretmene ulaşılması hedeflenmişken sınırlı sayıda bireye ulaşılabildiğinden örnekleme etkisi, bu araştırmanın dış geçerliğini etkileyen en önemli faktördür.

Bu örneklemde 2019-2020 eğitim ve öğretim yılı güz döneminde 23 farklı ildeki herhangi bir IB okulu, IB aday okulu, devlet okulu veya özel okulda çalışan 168 öğretmen bulunmaktadır. Öğretmenlerin 84'ü (\%50) devlet okulunda, 30'u (\%18) IB okulunda (6'sı IB aday okulunda), 54'ü (\%32) özel okulda öğretmenlik yapmaktadır. IB aday okulundaki katılımcıların sayısı az olduğu için IB okulundaki katılımcılara dâhil edilmiştir. Bu araştırmada okulların ölçülen özellik açısından karşılaştırılması amaçlandığından IB ilk yıllar, orta yıllar ve diploma programı uygulayan okullardaki öğretmen sayısı evrendeki okul oranlarına göre daha yüksek tutulmuştur. Katılımcıların 95'i (\%56) kadın ve 73'ü (\%44) erkektir. Katılımcıların 26'sı (\%16) okul öncesi, 44'ü (\%26) ilkokul, 51'i (\%31) ortaokul ve 52 'si (\%31) lise kademesinde görev yapmaktadır (Birden fazla kademede görev yapan öğretmenler bulunmaktadır.). Lisansüstü eğitimini tamamlamış ya da devam eden öğretmenlerin sayısının devlet okulunda 31 (\%37), IB okulunda 19 (\%63), özel okulda 14 (\%26) olduğu görülmektedir. Katılımcıların tecrübeleri incelendiğinde ise devlet okullarındaki öğretmenlerin 52'sinin (\%62), IB okullarındaki öğretmenlerin 8'inin (\%27) ve özel okullardaki öğretmenlerin 24'ünün (\%44) tecrübelerinin 10 yıl ve altında olduğu görülmüştür.

\section{Veri Toplama Aracı}

Veriler, araştırmacılar tarafından hazırlanan bir anket ile toplanmıştır. Soruların uygunluğu için üçü Ölçme ve Değerlendirme, ikisi Eğitim Programları ve Öğretim alanlarında akademisyen olan beş kişiden uzman görüşü alınmıştır. Uzmanlardan dördü Uluslararası Bakalorya Eğitimci Sertifikası (IBEC) programında eğitici olarak görev yapmaktadırlar. Tüm soruların uygunluğu konusunda hemfikir olan 
Merve Yıldırım Seheryeli, Selahattin Gelbal- Uluslararası Eğitim Programları ve Öğretim Çalışmaları Dergisi, 10(1), 2020, 221-260 uzmanlar form tasarımlarının IB için özelleştirilmesi ve metinsel düzeltmeler önermişlerdir. IB öğretmenleri için farklılaşan sorular aşağıdaki gibidir:

"IB okulunda öğretmen olarak toplam çalışma süreniz", "Görev yaptığınız IB Programı", "MEB'de çalışan öğretmenler için Ölçme ve Değerlendirme ne ifade ediyor? Açıklar mısınız?"

Anketin birinci bölümünde katılımcılara ait demografik özellikler ve ölçme ve değerlendirmeye ilişkin ilk izlenimleri, ikinci bölümünde ölçme ve değerlendirme araçlarını kullanım, kayıt altına alma ve geribildirim için kullanma sıklıkları, üçüncü bölümde ise yaşadıkları zorluklara ilişkin görüşleri ve programın paydaşlarına önerileri yer almaktadır. Toplam 26 sorudan oluşan anket Google tarayıcısında "Google Formlar" kullanılarak internet aracılığı ile uygulanmıştır. Ankette yaşadıkları zorluklar ve paydaşlara öneriler bölümü sorularına verilen yanıtlar diğer soruların yanıtları ile benzer bulgular oluşturduğundan ve kelime sınırlaması nedeniyle raporlanmamıştır.

\section{Verilerin Analizi}

Anketin birinci ve ikinci bölümünde yer alan nicel veriler SPSS 25 programı kullanılarak analiz edilmiştir. Verilerin analizinde elde edilen bilgilerin betimlenmesi için yüzde ve frekanslar incelenmiş, frekans dağılımları için kay-kare ( $\chi 2)$ testinden yararlanılmıştır. Açık uçlu sorulara verilen yanıtlar için ise betimsel analizler yapılmıştır. Betimsel analizde öğretmenlerin en sık kullandıkları kavramlar belirlenmiş ve başlıklandırılmıştır. Tablolardaki kavramlar, frekansları en az iki ya da üç olacak şekilde sınırlandırılmış, bazı karşılaştırmaları yapabilmek için frekansı bir olan kavramlar da eklenmiştir.

\section{Etik Konular}

Araştırmanın verileri İnternet üzerinden gönüllülük esası ile toplanmıştır. Bu nedenle katılımcılar için kullanılan yönergede isimlerinin kaydedilmeyeceği, verdikleri yanıtların araştırma dışında kullanılmayacağı, çalışmaya katılmama veya katıldıktan sonra herhangi bir anda çalışmadan çıkma hakkına sahip oldukları, çalışmaya katılmaları nedeni ile herhangi bir ücret alış-verişi olmayacağı belirtilmiştir. Buna ek olarak yönergeye aşağıdaki açıklama da eklenmiştir.

Formun sonunda "Gönder" butonunu tıkladığınızda aşağıdaki ifadeye katıldığınızı beyan etmiş olacaksınız. "Araştırma ile ilgili bana yapılan tüm açıklamaları ayrıntılarıyla anlamış bulunmaktayım. Bu çalışmaya hiçbir baskı altında kalmadan kendi bireysel onayım ile katılıyorum."

\section{Bulgular}

\section{Ölçme ve değerlendirme ile ilişkilendirilen kavramlar}

"Devlet okulu, IB okulları ve özel okuldaki öğretmenlerin "ölçme ve değerlendirme" dendiğinde ilk olarak hangi kavramlar akıllarına gelmektedir?" sorusuna ilişkin elde edilen verilerde öğretmenlerin açık uçlu sorulara verdikleri yanıtlar incelenmiştir. Tüm görüşlerin beş ana başlıkta toplandığı görülmektedir. Bu başlıklar "Temel Kavramlar”, "İstatistik”, "Neyi Ölçeriz?”, “Neden Ölçeriz?” ve "Nasıl Ölçeriz?" olarak belirlenmiştir.

Okullara göre "Temel Kavramlar" başlığı altında toplanan anahtar kelimeler geçerlik, güvenirlik, ölçek, ölçüt, değerlendirme, adalet, süreç değerlendirme olmuştur. Tüm katılımcılar baz alındığında öğretmenler, ölçme ve değerlendirmenin temel kavramları ile ilgili devlet okullarında 76, özel okullarda 22, IB okullarında ise 26 görüş bildirmişlerdir. En çok öne çıkan kavramlar devlet okullarında geçerlik ve güvenirlik, özel okullarda geçerlik ve süreç değerlendirme, IB okullarında ise süreç ve sonuç değerlendirme olmuştur. Yalnız IB okullarında rastlanan kavramların ise adalet ve bütünsel değerlendirme olduğu söylenebilir.

Okullara göre "istatistik" başlığı altında toplanan anahtar kelimeler standart sapma, güçlük, ayırt edicilik, analiz, mod-medyan, madde analizi olmuştur. Tüm katılımcılar baz alındığında öğretmenler, istatistik ile ilgili devlet okullarında 29, özel okullarda 9, IB okullarında ise 2 görüş bildirmişlerdir. En çok 
Merve Yıldırım Seheryeli, Selahattin Gelbal- Uluslararası Eğitim Programları ve Öğretim Çalışmaları Dergisi, 10(1), 2020, 221-260 öne çıkan kavramlar devlet okullarında standart sapma ve madde güçlüğü, özel okullarda madde analizi ve standart sapma, IB okullarında da benzer şekilde madde analizi olmuştur.

Okullara göre "Neyi ölçeriz?" başlığı altında toplanan anahtar kelimeler kazanım, performans, başarı, öğrenme düzeyi, taksonomi, belirtke, süreç, beceri, kazanım olmuştur. Tüm katılımcılar baz alındığında öğretmenler, "Neyi ölçeriz?" sorusuna yanıt olacak şekilde devlet okullarında 49, özel okullarda 22, IB okullarında ise 21 görüş bildirmişlerdir. En çok öne çıkan kavramlar devlet okullarında kazanım ve performans, özel okullarda başarı ve kazanım, IB okullarında süreç, kazanım ve beceri olmuştur.

Okullara göre "Neden ölçeriz?" başlığı altında toplanan anahtar kelimeler geribildirim, eğitim kalitesi ve öğrenciyi güdüleme, durum belirleme, dönüşümlü düşünme, kaliteyi arttırma, eksik belirleme, farklılaştırma, öğrenmeyi geliştirme, planlama, raporlama olmuştur. Tüm katılımcılar baz alındığında öğretmenler, "Neden ölçeriz?" sorusuna yanıt olacak şekilde devlet okullarında 28, özel okullarda 12, IB okullarında ise 36 görüş bildirmişlerdir. En çok öne çıkan kavramın her üç okul türünde de geribildirim olduğu görülmektedir. Yalnız IB okullarında rastlanan kavramların ise çözüm üretme, dönüşümlü düşünme, farklılaştırma, ihtiyaç belirleme, planlama ve raporlama olduğu söylenebilir.

Okullara göre "Nası ölçeriz?" başlığı altında toplanan anahtar kelimelerin sınav, soru, test, yazılı, gözlem, puan, açık uçlu, çoktan seçmeli, not, portfolyo, rubrik, süreç analizi, yansıtma, proje, gözlem, grup çalışması, ödev olduğu görülmüştür. Tüm katılımcılar baz alındığında öğretmenler, "Nasıl ölçeriz?" sorusuna yanıt olacak şekilde devlet okullarında 91, özel okullarda 46, IB okullarında ise 21 görüş bildirmişlerdir. En çok öne çıkan kavramların devlet okullarında sınav, soru ve test; özel okullarda sınav, test ve rubrik; IB okullarında rubrik ve süreç odaklı araçlar olduğu görülmektedir. Yalnız IB okullarında rastlanan kavramların ise anekdot, sunum ve yansıtma olduğu söylenebilir.

\section{Ölçme ve değerlendirme sistemine ilişkin görüşler ve bu sisteme katkılar}

"Devlet okulu, özel okul ve IB okullarında görev yapan öğretmenler bir ölçme ve değerlendirme sistemine tabi olduklarını düşünüyorlar mıdır?" sorusuna ilişkin veriler için Kay-kare fark testi sonuçları Tablo 1'de verilmiştir.

Tablo 1.

Öğretmenlerin Okullarında Uygulanan Bir Ölçme ve Değerlendirme Sisteminin Varlığı ile IIgili Görüşlerine Ilişkin Kay-Kare Testi Sonuçları

\begin{tabular}{|c|c|c|c|c|c|c|c|}
\hline & & Var & Yok & Toplam & Kay-kare & sd & $\mathbf{p}$ \\
\hline \multirow[t]{2}{*}{ Devlet okulu } & $\mathrm{N}$ & 40 & 44 & 84 & 34.531 & 2 & $0.000^{*}$ \\
\hline & $\%$ & $47.6 \%$ & $52.4 \%$ & $100.0 \%$ & & & \\
\hline \multirow[t]{2}{*}{ IB Okulu } & $\mathrm{N}$ & 25 & 5 & 30 & & & \\
\hline & $\%$ & $83.3 \%$ & $16.7 \%$ & $100.0 \%$ & & & \\
\hline \multirow[t]{2}{*}{ Özel Okul } & $\mathrm{N}$ & 50 & 4 & 54 & & & \\
\hline & $\%$ & $92.6 \%$ & $7.4 \%$ & $100.0 \%$ & & & \\
\hline \multirow[t]{2}{*}{ Toplam } & $\mathrm{N}$ & 115 & 53 & 168 & & & \\
\hline & $\%$ & $68.5 \%$ & $31.5 \%$ & $100.0 \%$ & & & \\
\hline
\end{tabular}

$* p<0.05$.

Tablo 1 incelendiğinde devlet okulundaki öğretmenlerin \%48'i okullarında bir ölçme ve değerlendirme sistemi olduğunu düşünürken $\% 52$ 'si olmadığını düşünmektedir. IB okullarındaki öğretmenlerin ise \%83'ü uygulanan bir ölçme ve değerlendirme sisteminin bulunduğunu, \%17'si bulunmadığını düşünmektedir. Özel okullarda çalışan öğretmenlerde bir ölçme ve değerlendirme sistemi bulunmadığını düşünenlerin oranı ise \%7'ye düşerken sistemin var olduğunu düşünenlerin oranı \%93'e yükselmiştir. Oranlar arasındaki bu farklılaşma 0,05 düzeyinde istatistiksel olarak anlamlı bulunmuştur $\left(\chi^{2}=34.531 ; s d=2 ; p<0.05\right)$. Okullarında bir ölçme ve değerlendirme sistemi olup olmadığına ilişkin görüşleri okul türlerine göre değişmektedir. 
Merve Yıldırım Seheryeli, Selahattin Gelbal- Uluslararası Eğitim Programları ve Öğretim Çalışmaları Dergisi, 10(1), 2020, 221-260

Okullarında bir ölçme ve değerlendirme sistemi bulunduğu görüşünde olan öğretmenlerin bu sistemi hayata geçirmek için neler yaptıkları incelendiğine ise bu çalışmaların beş başlık altında toplandığı görülmüştür. Bu başlıklar "Düzey Belirleme", "Öğrenmeyi Pekiştirme", "Sistemin Niteliğine Katkı", "Değerlendirme" ve "Kaydetme" olarak belirlenmiştir.

"Okullara Göre Düzey Belirleme" başlığı altında toplanan anahtar kelimeler yazılı sınav, soru cevap, sözlü sınav, kazanım değerlendirme, hazır denemeler, öğretmen tarafından kazanıma veya taksonomiye uygun hazırlanan sorular, yeni nesil sorular, test, becerilerin ölçülmesi olmuştur. Çalıştıkları okulda bir ölçme ve değerlendirme sistemi bulunduğunu ve bu sistemi hayata geçirmek için düzey belirleme çalışmaları yaptıklarını belirten öğretmenler; devlet okullarında 32, özel okullarda 39 ve IB okullarında 14 görüş belirtilmiştir. En çok öne çıkan düzey belirleme çalışmaları devlet okullarında deneme sınavı ve soru-cevap; özel okullarda öğretmen tarafından yazılan sorular, hazır denemeler ve kazanım değerlendirme; IB okullarında deneme sınavları olmuştur. Yalnız özel okullarda rastlanan çalışmaların ise becerilerin ölçülmesi, kazanıma-taksonomiye uygun soru yazma ve yeni nesil sorular olduğu söylenebilir.

"Okullara Göre Öğrenmeyi Pekiştirme" başlığı altında toplanan anahtar kelimeler ödev, ödül veya cezayı puanlama, tekrar, sorgulama çalışmaları olmuştur. Çalıştıkları okulda bir ölçme ve değerlendirme sistemi bulunduğunu ve bu sistemi hayata geçirmek için öğrenmeyi pekiştirme çalışmaları yaptıklarını belirten öğretmenler; devlet okullarında 8, özel okullarda 4 ve IB okullarında 5 görüş belirtmiştir. En çok öne çıkan öğrenmeyi pekiştirme çalışmaları devlet okullarında ödev ve tekrar; özel okullarda tekrar; IB okullarında sorgulama çalışmaları olmuştur. Yalnız IB okullarında rastlanan çalışmaların ise sorgulama çalışmaları olduğu söylenebilir.

"Okullara Göre Sistemin Niteliğine Katkı" başlığı altında toplanan anahtar kelimeler adaletli davranma, eğlenceli olmasını sağlama, zümre işbirliği, kelebek sistem, rahat sınıf ortamları, Web 2.0 araçları, anlaşılabilir olmasını sağlama, Ar-Ge ekibinin olması, bireysel farklılıkları dikkate alma, günlük hayatla ilişkilendirme, disiplinler arası çalışma, intihal programı kullanma, kriterleri öğrencilerle belirleme ya da öğrencileri kriterlerden haberdar etme olmuştur. Çalıştıkları okulda bir ölçme ve değerlendirme sistemi bulunduğunu ve bu sistemi hayata geçirmek için sistemin niteliğine katkı sağlayacak çalışmalar yaptıklarını belirten öğretmenler; devlet okullarında 8, özel okullarda 11 ve IB okullarında 15 görüş belirtmiştir. En çok öne çıkan sistemin niteliğine katkı sağlayacak çalışmalar devlet okullarında adaletli olma; özel okullarda bireysel farklılıkları dikkate alma ve zümrelerle işbirliği içinde olma; IB okullarında disiplinler arası çalışmalar ve zümrelerle işbirliği, kriterlerin öğrencilerle birlikte hazırlanması ya da onları kriterlerden haberdar etme olmuştur. Yalnız IB okullarında rastlanan çalışmaların ise adaletli olma, ar-ge ekibi, öğrencilerin ölçme ve değerlendirme süreçlerinde aktif olmasını sağlama; yalnız özel okullarda rastlanan çalışmaların ise kelebek sistem, intihal programları ve Web 2.0 araçları olduğu söylenebilir.

"Okullara Göre Değerlendirme" başlığı altında toplanan anahtar kelimeler geribildirim, gözlem formları, performans değerlendirme, portfolyo, öz-akran değerlendirme, süreç odaklı değerlendirme, rubrik, kriter bazlı değerlendirme olmuştur. Çalıştıkları okulda bir ölçme ve değerlendirme sistemi bulunduğunu ve bu sistemi hayata geçirmek için değerlendirme çalışmaları yaptıklarını belirten öğretmenler; devlet okullarında 26, özel okullarda 35 ve IB okullarında 20 görüş belirtmiştir. En çok öne çıkan değerlendirme çalışmaları devlet okullarında geribildirim ve performans değerlendirme; özel okullarda geribildirim ve süreç odaklı değerlendirme; IB okullarında rubrik ve süreç odaklı değerlendirme olmuştur. Yalnız IB okullarında rastlanan çalışmaların ise öz farkındalık, ölçekler ve rubrik olduğu söylenebilir.

"Okullara Göre Kaydetme" başlığı altında toplanan anahtar kelimeler analiz sonuçları, gelişim raporları, eğitimi planlama olmuştur. Çalıştıkları okulda bir ölçme ve değerlendirme sistemi bulunduğunu ve bu sistemi hayata geçirmek için elde edilen bilgilerin kaydedildiğini belirten öğretmenler; devlet okullarında 2, özel okullarda 1 ve IB okullarında 10 görüş belirtmiştir. Analiz, 
Merve Yıldırım Seheryeli, Selahattin Gelbal- Uluslararası Eğitim Programları ve Öğretim Çalışmaları Dergisi, 10(1), 2020, 221-260 raporlama gibi çalışmalardan birer kez bahsedilmiş olsa da planlama ve eğitimi planlama çalışmaları özellikle IB okullarında öne çıkmıştır.

\section{Araç ve tekniklerin kullanım, elde edilen bilgilerin kayıt altına alınma ve paylaşılma sıklıkları}

Bu alt probleme ilişkin bulgular dört başlık altında incelenmiştir. Öğretmenlerin ölçme araçlarını (a) kullanma, (b) kayıt altına alma, (c) öğrencilerle ve (d) velilerle paylaşma sıklıklarına ilişkin bilgiler için 10 farklı ölçme ve değerlendirme araç ve tekniğini "1: Hiçbir zaman, 2: Yılda bir kez, 3: Dönemde bir kez, 4: Ayda bir kez, 5: Haftada bir kez, 6: Her zaman" şeklinde puanlamaları istenmiştir. Okullar arasında bu dört başlığın farklılaşıp farklılaşmadığına ilişkin Kay-kare fark testi yapılımıştır. 0,05 düzeyinde anlamlılık testine ilişkin sonuçların doğru yorumlanabilmesi için beklenen değeri 5 'ten küçük olan gözenek sayısının \%20'yi aşmaması gerekmektedir (Field, 2009). Bu nedenle gözenek sayıları incelenmiş 1, 2 ve 3. kategoriler "en fazla dönemde bir kez", 5 ve 6. kategoriler "en az haftada bir kez" olarak birleştirilmiştir.

Devlet okulu, IB okulu ve özel okullarda görev yapan öğretmenlerin ölçme ve değerlendirme araçlarını/tekniklerini kullanma sıkıklarına ilişkin kay-kare testi sonuçları Tablo 2'de verilmiştir. Yalnız öğrencileri "gözlemleme" ve "geribildirim"e ilişkin frekans tablolarında \%20'den az olması beklenen oranı sağlayabilmek için 1, 2, 3 ve 4. kategoriler "en fazla ayda bir kez" olarak birleştirilmiştir.

Tablo 2.

Öğretmenlerin Görev Yaptıkları Okul Türüne Göre Ölçme ve Değerlendirme Araç ve Tekniklerini Kullanım Sıklıklarına ilişskin Kay-Kare Testi Sonuçları

\begin{tabular}{|c|c|c|c|c|c|c|c|c|c|}
\hline & & & $\begin{array}{c}\text { En fazla } \\
\text { dönemde } \\
1 \mathrm{kez}\end{array}$ & $\begin{array}{c}\text { Ayda } 1 \\
\text { kez }\end{array}$ & $\begin{array}{c}\text { En az } \\
\text { haftada } 1 \\
\text { kez }\end{array}$ & Toplam & $\begin{array}{l}\text { Kay- } \\
\text { kare }\end{array}$ & sd & $p$ \\
\hline \multirow{8}{*}{$\begin{array}{c}\text { Öz } \\
\text { değerlendirme }\end{array}$} & Devlet Okulu & $\mathrm{N}$ & 40 & 16 & 28 & 84 & 18.074 & 4 & $0.001^{*}$ \\
\hline & & $\%$ & $47.6 \%$ & $19.0 \%$ & $33.3 \%$ & $100.0 \%$ & & & \\
\hline & IB Okulu & $\mathrm{N}$ & 6 & 2 & 22 & 30 & & & \\
\hline & & $\%$ & $20.0 \%$ & $6.7 \%$ & $73.3 \%$ & $100.0 \%$ & & & \\
\hline & Özel Okul & $\mathrm{N}$ & 14 & 13 & 27 & 54 & & & \\
\hline & & $\%$ & $25.9 \%$ & $24.1 \%$ & $50.0 \%$ & $100.0 \%$ & & & \\
\hline & Toplam & $\mathrm{N}$ & 60 & 31 & 77 & 168 & & & \\
\hline & & $\%$ & $35.7 \%$ & $18.5 \%$ & $45.8 \%$ & $100.0 \%$ & & & \\
\hline \multirow{8}{*}{$\begin{array}{c}\text { Akran } \\
\text { değerlendirme }\end{array}$} & Devlet Okulu & $\mathrm{N}$ & 50 & 9 & 25 & 84 & 19.675 & 4 & $0.001^{*}$ \\
\hline & & $\%$ & $59.5 \%$ & $10.7 \%$ & $29.8 \%$ & $100.0 \%$ & & & \\
\hline & IB Okulu & $\mathrm{N}$ & 6 & 9 & 15 & 30 & & & \\
\hline & & $\%$ & $20.0 \%$ & $30.0 \%$ & $50.0 \%$ & $100.0 \%$ & & & \\
\hline & Özel Okul & $\mathrm{N}$ & 17 & 11 & 26 & 54 & & & \\
\hline & & $\%$ & $31.5 \%$ & $20.4 \%$ & $48.1 \%$ & $100.0 \%$ & & & \\
\hline & Toplam & $\mathrm{N}$ & 73 & 29 & 66 & 168 & & & \\
\hline & & $\%$ & $43.5 \%$ & $17.3 \%$ & $39.3 \%$ & $100.0 \%$ & & & \\
\hline \multirow[t]{8}{*}{ Kontrol listesi } & Devlet Okulu & $\mathrm{N}$ & 42 & 14 & 28 & 84 & 12.856 & 4 & $0.012^{*}$ \\
\hline & & $\%$ & $50.0 \%$ & $16.7 \%$ & $33.3 \%$ & $100.0 \%$ & & & \\
\hline & IB Okulu & $\mathrm{N}$ & 5 & 7 & 18 & 30 & & & \\
\hline & & $\%$ & $16.7 \%$ & $23.3 \%$ & $60.0 \%$ & $100.0 \%$ & & & \\
\hline & Özel Okul & $\mathrm{N}$ & 16 & 11 & 27 & 54 & & & \\
\hline & & $\%$ & $29.6 \%$ & $20.4 \%$ & $50.0 \%$ & $100.0 \%$ & & & \\
\hline & Toplam & $\mathrm{N}$ & 63 & 32 & 73 & 168 & & & \\
\hline & & $\%$ & $37.5 \%$ & $19.0 \%$ & $43.5 \%$ & $100.0 \%$ & & & \\
\hline \multirow{6}{*}{$\begin{array}{c}\text { Puanlama } \\
\text { anahtarı } \\
\text { (Rubrik) }\end{array}$} & Devlet Okulu & $\mathrm{N}$ & 51 & 10 & 23 & 84 & 17.345 & 4 & $0.002^{*}$ \\
\hline & & $\%$ & $60.7 \%$ & $11.9 \%$ & $27.4 \%$ & $100.0 \%$ & & & \\
\hline & IB Okulu & $\mathrm{N}$ & 6 & 5 & 19 & 30 & & & \\
\hline & & $\%$ & $20.0 \%$ & $16.7 \%$ & $63.3 \%$ & $100.0 \%$ & & & \\
\hline & Özel Okul & $\mathrm{N}$ & 21 & 9 & 24 & 54 & & & \\
\hline & & & & 246 & & & & & \\
\hline
\end{tabular}


Merve Yıldırım Seheryeli, Selahattin Gelbal- Uluslararası Eğitim Programları ve Öğretim Çalışmaları Dergisi, 10(1), 2020, 221-260

Tablo 2 (Devamı)

$\begin{array}{cccccc} & \% & 38.9 \% & 16.7 \% & 44.4 \% & 100.0 \% \\ \text { Toplam } & \mathrm{N} & 78 & 24 & 66 & 168 \\ & \% & 46.4 \% & 14.3 \% & 39.3 \% & 100.0 \%\end{array}$

$* \mathrm{p}<0.05$.

Tablo 2'ye göre öğretmenlerin öğrencileri gözlemleme ve geribildirim verme, performans değerlendirme (sunum, tartışma, rol yapma vb.), çoktan seçmeli sorular ve açık uçlu görevleri kullanma sıklıklarının her üç okul türünde de haftada en az bir kez; portfolyo kullanma sıklıklarının her üç okul türünde de en fazla dönemde bir kez olduğu görülmektedir. Bu sıklıklar okul türüne göre farklılaşmamaktadır $(p<0.05)$. Bu nedenle bu araç ve tekniklere ilişkin değerlere tabloda yer verilmemiştir. Öğretmenler, devlet okulunda öz ve akran değerlendirmeyi, kontrol listelerini ve puanlama anahtarlarını dönemde en fazla bir kez kullandıklarını daha yüksek oranda belirtirken özel okullarda ve IB okullarında haftada en az bir kez kullandıklarını daha yüksek oranlarda belirtmişlerdir. Özellikle IB okullarındaki en yüksek oranlara kullanım sıklıklarının haftada en az bir kez olduğu durumlarda rastlanmaktadır. Oranlar arasındaki bu farklılıklar 0.05 düzeyinde anlamlı bulunmuştur. IB okullarında ve özel okullarda kullanım sıklığı genel olarak haftada en az bir kez iken devlet okullarında kullanım sıklığı genel olarak en fazla dönemde bir kez olarak gözlenmiştir.

Devlet okulu, IB okulu ve özel okullarda görev yapan öğretmenlerin ölçme ve değerlendirme sonucu elde ettikleri bilgileri kayıt altına alma sıklıklarına ilişkin kay-kare testi sonuçları Tablo 3'te verilmiştir.

Tablo 3.

Öğretmenlerin Görev Yaptıkları Okul Türüne Göre Ölçme ve Değerlendirme Sonuçlarını Kayıt Altına Alma Sıklıklarına ilişkin Kay-Kare Testi Sonuçları

\begin{tabular}{|c|c|c|c|c|c|c|c|c|c|}
\hline & & & $\begin{array}{c}\text { En fazla } \\
\text { dönemde } 1 \\
\text { kez }\end{array}$ & $\begin{array}{l}\text { Ayda } 1 \\
\text { kez }\end{array}$ & $\begin{array}{c}\text { En az } \\
\text { haftada } 1 \\
\text { kez }\end{array}$ & Toplam & Kay-kare & $\begin{array}{l}\text { s } \\
\text { d }\end{array}$ & $p$ \\
\hline \multirow{8}{*}{$\begin{array}{l}\text { Öğrencileri } \\
\text { gözlemleme }\end{array}$} & \multirow[t]{2}{*}{ Devlet Okulu } & $\mathrm{N}$ & 28 & 12 & 44 & 84 & 10.145 & 4 & $0.038^{*}$ \\
\hline & & $\%$ & $33.3 \%$ & $14.3 \%$ & $52.4 \%$ & $100.0 \%$ & & & \\
\hline & \multirow[t]{2}{*}{ IB Okulu } & $\mathrm{N}$ & 5 & 1 & 24 & 30 & & & \\
\hline & & $\%$ & $16.7 \%$ & $3.3 \%$ & $80.0 \%$ & $100.0 \%$ & & & \\
\hline & \multirow[t]{2}{*}{ Özel Okul } & $\mathrm{N}$ & 10 & 5 & 39 & 54 & & & \\
\hline & & $\%$ & $18.5 \%$ & $9.3 \%$ & $72.2 \%$ & $100.0 \%$ & & & \\
\hline & \multirow[t]{2}{*}{ Toplam } & $\mathrm{N}$ & 43 & 18 & 107 & 168 & & & \\
\hline & & $\%$ & $25.6 \%$ & $10.7 \%$ & $63.7 \%$ & $100.0 \%$ & & & \\
\hline \multirow[t]{8}{*}{ Geribildirim } & \multirow[t]{2}{*}{ Devlet Okulu } & $\mathrm{N}$ & 28 & 14 & 42 & 84 & 12.594 & 4 & $0.013^{*}$ \\
\hline & & $\%$ & $33.3 \%$ & $16.7 \%$ & $50.0 \%$ & $100.0 \%$ & & & \\
\hline & \multirow[t]{2}{*}{ IB Okulu } & $\mathrm{N}$ & 5 & 1 & 24 & 30 & & & \\
\hline & & $\%$ & $16.7 \%$ & $3.3 \%$ & $80.0 \%$ & $100.0 \%$ & & & \\
\hline & \multirow[t]{2}{*}{ Özel Okul } & $\mathrm{N}$ & 8 & 8 & 38 & 54 & & & \\
\hline & & $\%$ & $14.8 \%$ & $14.8 \%$ & $70.4 \%$ & $100.0 \%$ & & & \\
\hline & \multirow[t]{2}{*}{ Toplam } & $\mathrm{N}$ & 41 & 23 & 104 & 168 & & & \\
\hline & & $\%$ & $24.4 \%$ & $13.7 \%$ & $61.9 \%$ & $100.0 \%$ & & & \\
\hline \multirow{8}{*}{$\begin{array}{l}\text { Performans } \\
\text { değerlendirme } \\
\text { (sunum, } \\
\text { tartışma, rol } \\
\text { yapma, vb.) }\end{array}$} & \multirow[t]{2}{*}{ Devlet Okulu } & $\mathrm{N}$ & 39 & 15 & 30 & 84 & 16.759 & 4 & $0.002 *$ \\
\hline & & $\%$ & $46.4 \%$ & $17.9 \%$ & $35.7 \%$ & $100.0 \%$ & & & \\
\hline & \multirow[t]{2}{*}{ IB Okulu } & $\mathrm{N}$ & 3 & 6 & 21 & 30 & & & \\
\hline & & $\%$ & $10.0 \%$ & $20.0 \%$ & $70.0 \%$ & $100.0 \%$ & & & \\
\hline & \multirow[t]{2}{*}{ Özel Okul } & $\mathrm{N}$ & 14 & 9 & 31 & 54 & & & \\
\hline & & $\%$ & $25.9 \%$ & $16.7 \%$ & $57.4 \%$ & $100.0 \%$ & & & \\
\hline & \multirow[t]{2}{*}{ Toplam } & $\mathrm{N}$ & 56 & 30 & 82 & 168 & & & \\
\hline & & $\%$ & $33.3 \%$ & $17.9 \%$ & $48.8 \%$ & $100.0 \%$ & & & \\
\hline
\end{tabular}


Merve Yıldırım Seheryeli, Selahattin Gelbal- Uluslararası Eğitim Programları ve Öğretim Çalışmaları Dergisi, 10(1), 2020, 221-260 Tablo 3 (Devamı)

\begin{tabular}{|c|c|c|c|c|c|c|c|c|c|}
\hline \multirow[t]{8}{*}{ Portfolyo } & \multirow[t]{2}{*}{ Devlet Okulu } & $\mathrm{N}$ & 58 & 6 & 20 & 84 & 17.698 & 4 & $0.001 *$ \\
\hline & & $\%$ & $69.0 \%$ & $7.1 \%$ & $23.8 \%$ & $100.0 \%$ & & & \\
\hline & \multirow[t]{2}{*}{ IB Okulu } & $\mathrm{N}$ & 14 & 0 & 16 & 30 & & & \\
\hline & & $\%$ & $46.7 \%$ & $0.0 \%$ & $53.3 \%$ & $100.0 \%$ & & & \\
\hline & \multirow[t]{2}{*}{ Özel Okul } & $\mathrm{N}$ & 25 & 10 & 19 & 54 & & & \\
\hline & & $\%$ & $46.3 \%$ & $18.5 \%$ & $35.2 \%$ & $100.0 \%$ & & & \\
\hline & \multirow[t]{2}{*}{ Toplam } & $\mathrm{N}$ & 97 & 16 & 55 & 168 & & & \\
\hline & & $\%$ & $57.7 \%$ & $9.5 \%$ & $32.7 \%$ & $100.0 \%$ & & & \\
\hline \multirow{8}{*}{$\begin{array}{l}\text { Öz } \\
\text { değerlendirme }\end{array}$} & \multirow[t]{2}{*}{ Devlet Okulu } & $\mathrm{N}$ & 47 & 10 & 27 & 84 & 22.201 & 4 & $0.000 *$ \\
\hline & & $\%$ & $56.0 \%$ & $11.9 \%$ & $32.1 \%$ & $100.0 \%$ & & & \\
\hline & \multirow[t]{2}{*}{ IB Okulu } & $\mathrm{N}$ & 5 & 2 & 23 & 30 & & & \\
\hline & & $\%$ & $16.7 \%$ & $6.7 \%$ & $76.7 \%$ & $100.0 \%$ & & & \\
\hline & \multirow[t]{2}{*}{ Özel Okul } & $\mathrm{N}$ & 17 & 10 & 27 & 54 & & & \\
\hline & & $\%$ & $31.5 \%$ & $18.5 \%$ & $50.0 \%$ & $100.0 \%$ & & & \\
\hline & \multirow[t]{2}{*}{ Toplam } & $\mathrm{N}$ & 69 & 22 & 77 & 168 & & & \\
\hline & & $\%$ & $41.1 \%$ & $13.1 \%$ & $45.8 \%$ & $100.0 \%$ & & & \\
\hline \multirow{8}{*}{$\begin{array}{l}\text { Akran } \\
\text { değerlendirme }\end{array}$} & \multirow[t]{2}{*}{ Devlet Okulu } & $\mathrm{N}$ & 54 & 8 & 22 & 84 & 20.725 & 4 & $0.000^{*}$ \\
\hline & & $\%$ & $64.3 \%$ & $9.5 \%$ & $26.2 \%$ & $100.0 \%$ & & & \\
\hline & \multirow[t]{2}{*}{ IB Okulu } & $\mathrm{N}$ & 7 & 3 & 20 & 30 & & & \\
\hline & & $\%$ & $23.3 \%$ & $10.0 \%$ & $66.7 \%$ & $100.0 \%$ & & & \\
\hline & \multirow[t]{2}{*}{ Özel Okul } & $\mathrm{N}$ & 20 & 8 & 26 & 54 & & & \\
\hline & & $\%$ & $37.0 \%$ & $14.8 \%$ & $48.1 \%$ & $100.0 \%$ & & & \\
\hline & \multirow[t]{2}{*}{ Toplam } & $\mathrm{N}$ & 81 & 19 & 68 & 168 & & & \\
\hline & & $\%$ & $48.2 \%$ & $11.3 \%$ & $40.5 \%$ & $100.0 \%$ & & & \\
\hline \multirow[t]{8}{*}{ Kontrol listesi } & \multirow[t]{2}{*}{ Devlet Okulu } & $\mathrm{N}$ & 51 & 11 & 22 & 84 & 22.818 & 4 & $0.000 *$ \\
\hline & & $\%$ & $60.7 \%$ & $13.1 \%$ & $26.2 \%$ & $100.0 \%$ & & & \\
\hline & \multirow[t]{2}{*}{ IB Okulu } & $\mathrm{N}$ & 5 & 4 & 21 & 30 & & & \\
\hline & & $\%$ & $16.7 \%$ & $13.3 \%$ & $70.0 \%$ & $100.0 \%$ & & & \\
\hline & \multirow[t]{2}{*}{ Özel Okul } & $\mathrm{N}$ & 19 & 9 & 26 & 54 & & & \\
\hline & & $\%$ & $35.2 \%$ & $16.7 \%$ & $48.1 \%$ & $100.0 \%$ & & & \\
\hline & \multirow[t]{2}{*}{ Toplam } & $\mathrm{N}$ & 75 & 24 & 69 & 168 & & & \\
\hline & & $\%$ & $44.6 \%$ & $14.3 \%$ & $41.1 \%$ & $100.0 \%$ & & & \\
\hline \multirow{8}{*}{$\begin{array}{l}\text { Puanlama } \\
\text { anahtarı } \\
\text { (Rubrik) }\end{array}$} & \multirow[t]{2}{*}{ Devlet Okulu } & $\mathrm{N}$ & 52 & 10 & 22 & 84 & 23.61 & 4 & $0.000 *$ \\
\hline & & $\%$ & $61.9 \%$ & $11.9 \%$ & $26.2 \%$ & $100.0 \%$ & & & \\
\hline & \multirow[t]{2}{*}{ IB Okulu } & $\mathrm{N}$ & 6 & 3 & 21 & 30 & & & \\
\hline & & $\%$ & $20.0 \%$ & $10.0 \%$ & $70.0 \%$ & $100.0 \%$ & & & \\
\hline & \multirow[t]{2}{*}{ Özel Okul } & $\mathrm{N}$ & 19 & 11 & 24 & 54 & & & \\
\hline & & $\%$ & $35.2 \%$ & $20.4 \%$ & $44.4 \%$ & $100.0 \%$ & & & \\
\hline & Toplam & $\mathrm{N}$ & 77 & 24 & 67 & 168 & & & \\
\hline & & $\%$ & $45.8 \%$ & $14.3 \%$ & $39.9 \%$ & $100.0 \%$ & & & \\
\hline
\end{tabular}

Bu tabloya göre öğretmenlerin öğrencileri gözlemleme ve geribildirim ile elde ettikleri bilgileri kayıt altına alma sıklıkları en yüksek her okul türünde "en az haftada bir kez" olmakla birlikte bu oran IB okullarında diğerlerinden daha fazladır. Öğretmenlerin portfolyo ile elde ettikleri bilgileri kayıt altına alma sıklıklarının devlet okullarında ve özel okullarda en yüksek oranlarının en fazla dönemde bir kez, IB okullarında en yüksek oranlarının en az haftada bir kez olduğu görülmektedir. Performans değerlendirme, öz ve akran değerlendirme, kontrol listeleri ve puanlama anahtarı ile elde ettikleri bilgileri devlet okulunda dönemde en fazla bir kez kayıt altına aldıklarını en yüksek oranda belirtirken özel okullarda ve IB okullarında haftada en az bir kez kayıt altına aldıklarını en yüksek oranda belirtmişlerdir. Oranlar arasındaki bu farklılıklar 0.05 düzeyinde anlamlı bulunmuştur. Bu oranların en yüksek değeri IB okullarında gözlenmiştir. 
Merve Yıldırım Seheryeli, Selahattin Gelbal- Uluslararası Eğitim Programları ve Öğretim Çalışmaları Dergisi, 10(1), 2020, 221-260

Öğretmenlerin çoktan seçmeli sorular ile elde ettikleri bilgileri kayıt altına alma sıklıkları devlet okullarında ve IB okullarında en fazla dönemde bir kez, özel okullarda en az haftada bir kez olarak değişmektedir. Açık uçlu görevler ile elde ettikleri bilgileri kayıt altına alma sıklıkları ise her üç okul türünde de en yüksek olarak "en az haftada bir kez" olarak görülmektedir. Bu oranlar anlamlı farklılıklar göstermemektedir $(p<0.05)$. Bu nedenle bu sıklıklara ilişkin değerlere tabloda yer verilmemiştir. Devlet okulları, IB okulları ve özel okullarda çoktan seçmeli sorulardan ve açık uçlu görevlerden elde edilen bilgilerin kayıt altına alınma sıklıkları değişmemektedir.

Devlet okulu, IB okulu ve özel okullarda görev yapan öğretmenlerin ölçme ve değerlendirme sonuçlarını öğrencileri ile paylaşma sıklıklarına ilişkin kay-kare testi sonuçları Tablo 4'te verilmiştir.

Bu tabloya göre öğretmenlerin öğrencileri gözlemlemeleri ve açık uçlu görevler ile elde ettikleri bilgileri öğrencileri ile paylaşma sıklıkları üç okul türünde de "en fazla haftada en az bir kere" olarak belirtilmiştir. Portfolyo ile elde ettikleri bilgileri öğrencileri ile paylaşma sıklıkları ise üç okul türünde de en yüksek frekansın en fazla dönemde bir kez olduğu görülmektedir. Öğretmenlerin çoktan seçmeli sorular, performans değerlendirme, öz ve akran değerlendirme, kontrol listesi ve puanlama anahtarı ile elde ettikleri bilgileri öğrencileri ile paylaşma sıklıklarının devlet okullarında en fazla dönemde bir kez, özel okullarda ve IB okullarında en az haftada bir kez olduğu görülmektedir. Oranlar arasındaki bu farklılıklar 0.05 düzeyinde anlamlı bulunmuştur. Bu oranların en yüksek değeri IB okullarında gözlenmiştir.

Öğretmenlerin geribildirim ile elde ettikleri bilgileri öğrencileri ile paylaşma sıklıkları üç okul türünde de en fazla haftada en az bir kere olarak belirtilmiştir. Oranlar arasındaki bu farklılıklar 0.05 düzeyinde istatistiksel olarak anlamlı bulunmamıştır. Okul türleri arasında bir farklılık yoktur. Bu nedenle bu sıklıklara ilişkin değerlere tabloda yer verilmemiştir.

Tablo 4.

Öğretmenlerin Görev Yaptıkları Okul Türüne Göre Ölçme ve Değerlendirme Sonuçlarını Öğrencileri ile Paylaşma Sıklıklarına İlişkin Kay-Kare Testi Sonuçları

\begin{tabular}{|c|c|c|c|c|c|c|c|c|c|}
\hline & & & $\begin{array}{c}\text { En fazla } \\
\text { dönemde } 1 \\
\text { kez }\end{array}$ & $\begin{array}{l}\text { Ayda } \\
1 \mathrm{kez}\end{array}$ & $\begin{array}{c}\text { En az } \\
\text { haftada } 1 \\
\text { kez }\end{array}$ & Toplam & Kay-kare & sd & $\mathbf{p}$ \\
\hline \multirow{7}{*}{$\begin{array}{l}\text { Öğrencileri } \\
\text { gözlemleme }\end{array}$} & Devlet & $\mathrm{N}$ & 30 & 9 & 45 & 84 & 10.368 & 4 & $0.035^{*}$ \\
\hline & Okulu & $\%$ & $35.7 \%$ & $10.7 \%$ & $53.6 \%$ & $100.0 \%$ & & & \\
\hline & IB Okulu & $\mathrm{N}$ & 4 & 1 & 25 & 30 & & & \\
\hline & & $\%$ & $13.3 \%$ & $3.3 \%$ & $83.3 \%$ & $100.0 \%$ & & & \\
\hline & & $\%$ & $22.2 \%$ & $14.8 \%$ & $63.0 \%$ & $100.0 \%$ & & & \\
\hline & Toplam & $\mathrm{N}$ & 46 & 18 & 104 & 168 & & & \\
\hline & & $\%$ & $27.4 \%$ & $10.7 \%$ & $61.9 \%$ & $100.0 \%$ & & & \\
\hline \multirow{8}{*}{$\begin{array}{l}\text { Performans } \\
\text { değerlendirme } \\
\text { (sunum, } \\
\text { tartışma, rol } \\
\text { yapma, vb.) }\end{array}$} & Devlet & $\mathrm{N}$ & 43 & 10 & 31 & 84 & 17.97 & 4 & $0.001^{*}$ \\
\hline & Okulu & $\%$ & $51.2 \%$ & $11.9 \%$ & $36.9 \%$ & $100.0 \%$ & & & \\
\hline & IB Okulu & $\mathrm{N}$ & 4 & 5 & 21 & 30 & & & \\
\hline & & $\%$ & $13.3 \%$ & $16.7 \%$ & $70.0 \%$ & $100.0 \%$ & & & \\
\hline & Özel Okul & $\mathrm{N}$ & 16 & 13 & 25 & 54 & & & \\
\hline & & $\%$ & $29.6 \%$ & $24.1 \%$ & $46.3 \%$ & $100.0 \%$ & & & \\
\hline & Toplam & $\mathrm{N}$ & 63 & 28 & 77 & 168 & & & \\
\hline & & $\%$ & $37.5 \%$ & $16.7 \%$ & $45.8 \%$ & $100.0 \%$ & & & \\
\hline \multirow{7}{*}{$\begin{array}{l}\text { Çoktan seçmeli } \\
\text { sorular }\end{array}$} & Devlet & $\mathrm{N}$ & 39 & 12 & 33 & 84 & 9.576 & 4 & $0.048^{*}$ \\
\hline & Okulu & $\%$ & $46.4 \%$ & $14.3 \%$ & $39.3 \%$ & $100.0 \%$ & & & \\
\hline & IB Okulu & $\mathrm{N}$ & 11 & 1 & 18 & 30 & & & \\
\hline & & $\%$ & $36.7 \%$ & $3.3 \%$ & $60.0 \%$ & $100.0 \%$ & & & \\
\hline & Özel Okul & $\mathrm{N}$ & 17 & 13 & 24 & 54 & & & \\
\hline & & $\%$ & $31.5 \%$ & $24.1 \%$ & $44.4 \%$ & $100.0 \%$ & & & \\
\hline & Toplam & $\mathrm{N}$ & 67 & 26 & 75 & 168 & & & \\
\hline
\end{tabular}


Merve Yıldırım Seheryeli, Selahattin Gelbal- Uluslararası Eğitim Programları ve Öğretim Çalışmaları Dergisi, 10(1), 2020, 221-260 Tablo 4 (Devamı)

\begin{tabular}{|c|c|c|c|c|c|c|c|c|c|}
\hline & & $\%$ & $39.9 \%$ & $15.5 \%$ & $44.6 \%$ & $100.0 \%$ & & & \\
\hline Açık uçlu & Devlet & $\mathrm{N}$ & 31 & 19 & 34 & 84 & 11.674 & 4 & $0.020 *$ \\
\hline \multirow[t]{7}{*}{ görevler } & Okulu & $\%$ & $36.9 \%$ & $22.6 \%$ & $40.5 \%$ & $100.0 \%$ & & & \\
\hline & IB Okulu & $\mathrm{N}$ & 4 & 3 & 23 & 30 & & & \\
\hline & & $\%$ & $13.3 \%$ & $10.0 \%$ & $76.7 \%$ & $100.0 \%$ & & & \\
\hline & Özel Okul & $\mathrm{N}$ & 17 & 11 & 26 & 54 & & & \\
\hline & & $\%$ & $31.5 \%$ & $20.4 \%$ & $48.1 \%$ & $100.0 \%$ & & & \\
\hline & Toplam & $\mathrm{N}$ & 52 & 33 & 83 & 168 & & & \\
\hline & & $\%$ & $31.0 \%$ & $19.6 \%$ & $49.4 \%$ & $100.0 \%$ & & & \\
\hline \multirow[t]{8}{*}{ Portfolyo } & Devlet & $N$ & 63 & 5 & 16 & 84 & 14.721 & 4 & $0.005^{*}$ \\
\hline & Okulu & $\%$ & $75.0 \%$ & $6.0 \%$ & $19.0 \%$ & $100.0 \%$ & & & \\
\hline & IB Okulu & $\mathrm{N}$ & 15 & 2 & 13 & 30 & & & \\
\hline & & $\%$ & $50.0 \%$ & $6.7 \%$ & $43.3 \%$ & $100.0 \%$ & & & \\
\hline & Özel Okul & $N$ & 26 & 9 & 19 & 54 & & & \\
\hline & & $\%$ & $48.1 \%$ & $16.7 \%$ & $35.2 \%$ & $100.0 \%$ & & & \\
\hline & Toplam & $\mathrm{N}$ & 104 & 16 & 48 & 168 & & & \\
\hline & & $\%$ & $61.9 \%$ & $9.5 \%$ & $28.6 \%$ & $100.0 \%$ & & & \\
\hline Öz & Devlet & $\mathrm{N}$ & 50 & 8 & 26 & 84 & 21.423 & 4 & $0.000^{*}$ \\
\hline \multirow[t]{7}{*}{ değerlendirme } & Okulu & $\%$ & $59.5 \%$ & $9.5 \%$ & $31.0 \%$ & $100.0 \%$ & & & \\
\hline & IB Okulu & $\mathrm{N}$ & 5 & 4 & 21 & 30 & & & \\
\hline & & $\%$ & $16.7 \%$ & $13.3 \%$ & $70.0 \%$ & $100.0 \%$ & & & \\
\hline & Özel & $\mathrm{N}$ & 17 & 8 & 29 & 54 & & & \\
\hline & Okul & $\%$ & $31.5 \%$ & $14.8 \%$ & $53.7 \%$ & $100.0 \%$ & & & \\
\hline & Toplam & $\mathrm{N}$ & 72 & 20 & 76 & 168 & & & \\
\hline & & $\%$ & $42.9 \%$ & $11.9 \%$ & $45.2 \%$ & $100.0 \%$ & & & \\
\hline Akran & Devlet & $\mathrm{N}$ & 56 & 11 & 17 & 84 & 23.775 & 4 & $0.000^{*}$ \\
\hline \multirow[t]{7}{*}{ değerlendirme } & Okulu & $\%$ & $66.7 \%$ & $13.1 \%$ & $20.2 \%$ & $100.0 \%$ & & & \\
\hline & IB Okulu & $\mathrm{N}$ & 7 & 5 & 18 & 30 & & & \\
\hline & & $\%$ & $23.3 \%$ & $16.7 \%$ & $60.0 \%$ & $100.0 \%$ & & & \\
\hline & Özel & $\mathrm{N}$ & 20 & 8 & 26 & 54 & & & \\
\hline & Okul & $\%$ & $37.0 \%$ & $14.8 \%$ & $48.1 \%$ & $100.0 \%$ & & & \\
\hline & Toplam & $\mathrm{N}$ & 83 & 24 & 61 & 168 & & & \\
\hline & & $\%$ & $49.4 \%$ & $14.3 \%$ & $36.3 \%$ & $100.0 \%$ & & & \\
\hline \multirow[t]{8}{*}{ Kontrol listesi } & Devlet & $\mathrm{N}$ & 53 & 8 & 23 & 84 & 21.421 & 4 & $0.000^{*}$ \\
\hline & Okulu & $\%$ & $63.1 \%$ & $9.5 \%$ & $27.4 \%$ & $100.0 \%$ & & & \\
\hline & IB Okulu & $\mathrm{N}$ & 6 & 4 & 20 & 30 & & & \\
\hline & & $\%$ & $20.0 \%$ & $13.3 \%$ & $66.7 \%$ & $100.0 \%$ & & & \\
\hline & Özel & $\mathrm{N}$ & 20 & 10 & 24 & 54 & & & \\
\hline & Okul & $\%$ & $37.0 \%$ & $18.5 \%$ & $44.4 \%$ & $100.0 \%$ & & & \\
\hline & Toplam & $\mathrm{N}$ & 79 & 22 & 67 & 168 & & & \\
\hline & & $\%$ & $47.0 \%$ & $13.1 \%$ & $39.9 \%$ & $100.0 \%$ & & & \\
\hline \multirow{8}{*}{$\begin{array}{l}\text { Puanlama } \\
\text { anahtarı } \\
\text { (Rubrik) }\end{array}$} & Devlet & $\mathrm{N}$ & 53 & 9 & 22 & 84 & 19.807 & 4 & $0.001^{*}$ \\
\hline & Okulu & $\%$ & $63.1 \%$ & $10.7 \%$ & $26.2 \%$ & $100.0 \%$ & & & \\
\hline & IB Okulu & $\mathrm{N}$ & 7 & 4 & 19 & 30 & & & \\
\hline & & $\%$ & $23.3 \%$ & $13.3 \%$ & $63.3 \%$ & $100.0 \%$ & & & \\
\hline & Özel & $\mathrm{N}$ & 20 & 11 & 23 & 54 & & & \\
\hline & Okul & $\%$ & $37.0 \%$ & $20.4 \%$ & $42.6 \%$ & $100.0 \%$ & & & \\
\hline & Toplam & $\mathrm{N}$ & 80 & 24 & 64 & 168 & & & \\
\hline & & $\%$ & $47.6 \%$ & $14.3 \%$ & $38.1 \%$ & $100.0 \%$ & & & \\
\hline
\end{tabular}

${ }^{*} p<0.05$ 
Merve Yıldırım Seheryeli, Selahattin Gelbal- Uluslararası Eğitim Programları ve Öğretim Çalışmaları Dergisi, 10(1), 2020, 221-260

Devlet okulu, IB okulu ve özel okullarda görev yapan öğretmenlerin ölçme ve değerlendirme sonuçlarını veliler ile paylaşma sıkıklarına ilişkin kay-kare testi sonuçları Tablo 5 'te verilmiştir.

Tablo 5.

Öğretmenlerin Görev Yaptıkları Okul Türüne Göre Ölçme ve Değerlendirme Sonuçlarını Veliler ile Paylaşma Sıklıklarına Iliş̧kin Kay-Kare Testi Sonuçları

\begin{tabular}{|c|c|c|c|c|c|c|c|c|c|}
\hline & & & $\begin{array}{c}\text { En fazla } \\
\text { dönemde } \\
1 \mathrm{kez} \\
\end{array}$ & $\begin{array}{l}\text { Ayda } 1 \\
\text { kez }\end{array}$ & $\begin{array}{c}\text { En az } \\
\text { haftada } \\
1 \mathrm{kez}\end{array}$ & Toplam & Kay-kare & sd & $p$ \\
\hline \multirow[t]{8}{*}{ Geribildirim } & Devlet Okulu & $\mathrm{N}$ & 38 & 18 & 28 & 84 & 10.582 & 4 & $0.032^{*}$ \\
\hline & & $\%$ & $45.2 \%$ & $21.4 \%$ & $33.3 \%$ & $100.0 \%$ & & & \\
\hline & IB Okulu & $\mathrm{N}$ & 10 & 4 & 16 & 30 & & & \\
\hline & & $\%$ & $33.3 \%$ & $13.3 \%$ & $53.3 \%$ & $100.0 \%$ & & & \\
\hline & Özel Okul & $\mathrm{N}$ & 12 & 17 & 25 & 54 & & & \\
\hline & & $\%$ & $22.2 \%$ & $31.5 \%$ & $46.3 \%$ & $100.0 \%$ & & & \\
\hline & Toplam & $\mathrm{N}$ & 60 & 39 & 69 & 168 & & & \\
\hline & & $\%$ & $35.7 \%$ & $23.2 \%$ & $41.1 \%$ & $100.0 \%$ & & & \\
\hline \multirow{8}{*}{$\begin{array}{l}\text { Çoktan } \\
\text { seçmeli } \\
\text { sorular }\end{array}$} & Devlet Okulu & $\mathrm{N}$ & 51 & 15 & 18 & 84 & 12.285 & 4 & $0.015^{*}$ \\
\hline & & $\%$ & $60.7 \%$ & $17.9 \%$ & $21.4 \%$ & $100.0 \%$ & & & \\
\hline & IB Okulu & $\mathrm{N}$ & 18 & 3 & 9 & 30 & & & \\
\hline & & $\%$ & $60.0 \%$ & $10.0 \%$ & $30.0 \%$ & $100.0 \%$ & & & \\
\hline & Özel Okul & $\mathrm{N}$ & 18 & 13 & 23 & 54 & & & \\
\hline & & $\%$ & $33.3 \%$ & $24.1 \%$ & $42.6 \%$ & $100.0 \%$ & & & \\
\hline & Toplam & $\mathrm{N}$ & 87 & 31 & 50 & 168 & & & \\
\hline & & $\%$ & $51.8 \%$ & $18.5 \%$ & $29.8 \%$ & $100.0 \%$ & & & \\
\hline \multirow{8}{*}{$\begin{array}{l}\text { Açık uçlu } \\
\text { görevler }\end{array}$} & Devlet Okulu & $\mathrm{N}$ & 50 & 14 & 20 & 84 & 11.31 & 4 & $0.023^{*}$ \\
\hline & & $\%$ & $59.5 \%$ & $16.7 \%$ & $23.8 \%$ & $100.0 \%$ & & & \\
\hline & IB Okulu & $\mathrm{N}$ & 12 & 5 & 13 & 30 & & & \\
\hline & & $\%$ & $40.0 \%$ & $16.7 \%$ & $43.3 \%$ & $100.0 \%$ & & & \\
\hline & Özel Okul & $\mathrm{N}$ & 19 & 17 & 18 & 54 & & & \\
\hline & & $\%$ & $35.2 \%$ & $31.5 \%$ & $33.3 \%$ & $100.0 \%$ & & & \\
\hline & Toplam & $\mathrm{N}$ & 81 & 36 & 51 & 168 & & & \\
\hline & & $\%$ & $48.2 \%$ & $21.4 \%$ & $30.4 \%$ & $100.0 \%$ & & & \\
\hline \multirow[t]{8}{*}{ Portfolyo } & Devlet Okulu & $\mathrm{N}$ & 65 & 6 & 13 & 84 & 15.074 & 4 & $0.005^{*}$ \\
\hline & & $\%$ & $77.4 \%$ & $7.1 \%$ & $15.5 \%$ & $100.0 \%$ & & & \\
\hline & IB Okulu & $\mathrm{N}$ & 18 & 4 & 8 & 30 & & & \\
\hline & & $\%$ & $60.0 \%$ & $13.3 \%$ & $26.7 \%$ & $100.0 \%$ & & & \\
\hline & Özel Okul & $\mathrm{N}$ & 27 & 15 & 12 & 54 & & & \\
\hline & & $\%$ & $50.0 \%$ & $27.8 \%$ & $22.2 \%$ & $100.0 \%$ & & & \\
\hline & Toplam & $\mathrm{N}$ & 110 & 25 & 33 & 168 & & & \\
\hline & & $\%$ & $65.5 \%$ & $14.9 \%$ & $19.6 \%$ & $100.0 \%$ & & & \\
\hline \multirow{8}{*}{$\begin{array}{l}\text { Öz } \\
\text { değerlendirme }\end{array}$} & Devlet Okulu & $\mathrm{N}$ & 58 & 11 & 15 & 84 & 14.939 & 4 & $0.005^{*}$ \\
\hline & & $\%$ & $69.0 \%$ & $13.1 \%$ & $17.9 \%$ & $100.0 \%$ & & & \\
\hline & IB Okulu & $\mathrm{N}$ & 13 & 4 & 13 & 30 & & & \\
\hline & & $\%$ & $43.3 \%$ & $13.3 \%$ & $43.3 \%$ & $100.0 \%$ & & & \\
\hline & Özel Okul & $\mathrm{N}$ & 22 & 13 & 19 & 54 & & & \\
\hline & & $\%$ & $40.7 \%$ & $24.1 \%$ & $35.2 \%$ & $100.0 \%$ & & & \\
\hline & Toplam & $\mathrm{N}$ & 93 & 28 & 47 & 168 & & & \\
\hline & & $\%$ & $55.4 \%$ & $16.7 \%$ & $28.0 \%$ & $100.0 \%$ & & & \\
\hline \multirow{4}{*}{$\begin{array}{l}\text { Akran } \\
\text { değerlendirme }\end{array}$} & Devlet Okulu & $\mathrm{N}$ & 57 & 15 & 12 & 84 & 11.47 & 4 & $0.022 *$ \\
\hline & & $\%$ & $67.9 \%$ & $17.9 \%$ & $14.3 \%$ & $100.0 \%$ & & & \\
\hline & IB Okulu & $\mathrm{N}$ & 18 & 4 & 8 & 30 & & & \\
\hline & & $\%$ & $60.0 \%$ & $13.3 \%$ & $26.7 \%$ & $100.0 \%$ & & & \\
\hline
\end{tabular}


Merve Yıldırım Seheryeli, Selahattin Gelbal- Uluslararası Eğitim Programları ve Öğretim Çalışmaları Dergisi, 10(1), 2020, 221-260 Tablo 5

\begin{tabular}{|c|c|c|c|c|c|c|c|c|c|}
\hline \multirow[t]{4}{*}{ (Devamı) } & \multirow[t]{2}{*}{ Özel Okul } & $\mathrm{N}$ & 22 & 16 & 16 & 54 & & & \\
\hline & & $\%$ & $40.7 \%$ & $29.6 \%$ & $29.6 \%$ & $100.0 \%$ & & & \\
\hline & \multirow[t]{2}{*}{ Toplam } & $\mathrm{N}$ & 97 & 35 & 36 & 168 & & & \\
\hline & & $\%$ & $57.7 \%$ & $20.8 \%$ & $21.4 \%$ & $100.0 \%$ & & & \\
\hline \multirow[t]{8}{*}{ Kontrol listesi } & \multirow[t]{2}{*}{ Devlet Okulu } & $\mathrm{N}$ & 60 & 13 & 11 & 84 & 17.703 & 4 & $0.001 *$ \\
\hline & & $\%$ & $71.4 \%$ & $15.5 \%$ & $13.1 \%$ & $100.0 \%$ & & & \\
\hline & \multirow[t]{2}{*}{ IB Okulu } & $\mathrm{N}$ & 15 & 4 & 11 & 30 & & & \\
\hline & & $\%$ & $50.0 \%$ & $13.3 \%$ & $36.7 \%$ & $100.0 \%$ & & & \\
\hline & \multirow[t]{2}{*}{ Özel Okul } & $N$ & 21 & 14 & 19 & 54 & & & \\
\hline & & $\%$ & $38.9 \%$ & $25.9 \%$ & $35.2 \%$ & $100.0 \%$ & & & \\
\hline & \multirow[t]{2}{*}{ Toplam } & $\mathrm{N}$ & 96 & 31 & 41 & 168 & & & \\
\hline & & $\%$ & $57.1 \%$ & $18.5 \%$ & $24.4 \%$ & $100.0 \%$ & & & \\
\hline \multirow{8}{*}{$\begin{array}{l}\text { Puanlama } \\
\text { anahtarı } \\
\text { (Rubrik) }\end{array}$} & \multirow[t]{2}{*}{ Devlet Okulu } & $N$ & 60 & 10 & 14 & 84 & 11.757 & 4 & $0.019 *$ \\
\hline & & $\%$ & $71.4 \%$ & $11.9 \%$ & $16.7 \%$ & $100.0 \%$ & & & \\
\hline & \multirow[t]{2}{*}{ IB Okulu } & $\mathrm{N}$ & 15 & 4 & 11 & 30 & & & \\
\hline & & $\%$ & $50.0 \%$ & $13.3 \%$ & $36.7 \%$ & $100.0 \%$ & & & \\
\hline & \multirow[t]{2}{*}{ Özel Okul } & $N$ & 25 & 13 & 16 & 54 & & & \\
\hline & & $\%$ & $46.3 \%$ & $24.1 \%$ & $29.6 \%$ & $100.0 \%$ & & & \\
\hline & \multirow[t]{2}{*}{ Toplam } & $\mathrm{N}$ & 100 & 27 & 41 & 168 & & & \\
\hline & & $\%$ & $59.5 \%$ & $16.1 \%$ & $24.4 \%$ & $100.0 \%$ & & & \\
\hline
\end{tabular}

${ }^{*} p<0.05$

Bu tabloya göre öğretmenlerin öğrencileri gözlemleme ile elde ettikleri bilgileri velileri ile paylaşma sıkıklarının devlet okullarında en fazla dönemde bir kez, özel okullarda ve IB okullarında en az haftada bir kez olduğu görülmektedir. Performans değerlendirme ile elde ettikleri bilgileri velileri ile paylaşma sıkıklarının ise devlet okullarında en fazla dönemde bir kez, IB okullarında en fazla dönemde bir kez, özel okullarda en az haftada bir kez olduğu görülmektedir. Oranlar arasındaki bu farklılıklar 0.05 düzeyinde istatistiksel olarak anlamlı bulunmamıştır. Bu nedenle bu sıklıklara ilişkin değerlere tabloda yer verilmemiştir. Okullar arasında öğrencileri gözlemleme ve performans değerlendirme ile elde edilen bilgilerin veliler ile paylaşılma sıklığı arasında fark yoktur.

Öğretmenlerin geribildirim ile elde ettikleri bilgileri velileri ile paylaşma sıklığının devlet okullarında en fazla dönemde bir kez, özel okullarda ve IB okullarında en az haftada bir kez olduğu görülmektedir. Çoktan seçmeli sorular ile elde ettikleri bilgileri velileri ile paylaşma sıklıklarının devlet okullarında ve IB okullarında en fazla dönemde bir kez, özel okullarda en az haftada bir kez olduğu görülmektedir. Öğretmenlerin açık uçlu görevler ile elde ettikleri bilgileri velileri ile paylaşma sıklığının devlet okullarında ve özel okullarda en fazla dönemde bir kez, IB okullarında en az haftada bir kez olduğu; portfolyo, öz ve akran değerlendirme, kontrol listesi ve puanlama anahtarı ile elde ettikleri bilgileri velileri ile paylaşma sıklıklarının ise her üç okul türünde de en yüksek oranda "en fazla dönemde bir kez" olarak görülmektedir. Oranlar arasındaki bu farklılıklar 0.05 düzeyinde istatistiksel olarak anlamlı bulunmuştur. Okullar arasında bilgilerin veliler ile paylaşııma sıklığı farklılaşmaktadır. IB okullarında ve özel okullarda velilerle paylaşma sıklığı genel olarak haftada en az bir kez iken devlet okullarında velilerle paylaşma sıklığı genel olarak en fazla dönemde bir kez olarak gözlenmiştir. Bu oranların en yüksek değeri IB okullarında gözlenmiştir.

\section{Tartışma, Sonuç ve Öneriler}

Bu araştırmada Türkiye'deki IB okullarında ve MEB'e bağlı özel okullardaki ve devlet okullarındaki öğretmenlerin ölçme ve değerlendirme çalışmaları ve bu konudaki görüşleri incelenmiştir. Araştırmanın bulguları ilk olarak öğretmenlerin ölçme ve değerlendirme dendiğinde akıllarına gelen 
Merve Yıldırım Seheryeli, Selahattin Gelbal- Uluslararası Eğitim Programları ve Öğretim Çalışmaları Dergisi, 10(1), 2020, 221-260 kavramları içermektedir. Bu kavramlar "Temel kavramlar", "İstatistik”, "Neyi ölçeriz", "Neden ölçeriz?”, "Nasıl ölçeriz?" başlıklarında toplanmıştır.

"Temel kavramlar" başlı̆ı altında yalnız bir okulda rastlanan kavramların adalet ve bütünsel değerlendirme olduğu söylenebilir. Bütünsel değerlendirme kavramının IB okullarında daha ön planda olmasının özellikle Avrupa üniversitelerine sınavsız geçişte (IBO, 2018d) öğrenci hakkında karar vermede daha uygun bir yöntem olduğu düşünülmektedir. Devlet okullarında ve özel okullarda sonuç değerlendirmede sınavların ve testlerin çok kullanılması nedeniyle öğrencilerin sıralanmasına dayalı bir karar verme durumu daha çok kullanılmaktadır (Gelbal \& Kelecioğlu, 2007). Bu nedenle adalet kavramının farklılaştığı, IB okullarında yapılan bireysel gelişim için değerlendirmenin sıralama amacı olmadığından adalet kavramının öne çıkmadığı düşünülmektedir.

"Istatistik" başlığı altında en çok öne çıkan kavramların devlet okulları dışında benzer olduğu görülmüştür. Bu durumun nedeni, özel okullarda ve IB okullarında bir okul koordinatörü ya da ölçme ve değerlendirme uzmanı olmasıyla öğretmenlerin kendi yazdıkları soruları değerlendirme fırsatı bulması olabilir.

IB okullarında süreç değerlendirme çalışmaları daha ön plandadır, çünkü tam öğrenmenin gerçekleşmesi için, öğrencilerin bireysel farklılıklarına göre izleme ve geliştirme çalışmaları yapılmaktadır (IBO, 2018d). Dolayısı ile “Neyi ölçeriz?” sorusuna yanıt olacak şekilde öne çıkan kavramların IB okullarında süreç, kazanım ve beceri olması beklenen bir durumdur. Dolayısı ile özellikle öğretim programlarının bireyselleştirmeyi yalnız özel eğitime ihtiyaç duyulduğunda değil, her öğrencinin ihtiyacına göre farklılaşacak şekilde esnek bir yapıda oluşturması tam öğrenmeye de katkı sağlayacaktır (Ayyıldız \& Üzümcü, 2016).

"Neden ölçeriz?" sorusuna yanıt olacak şekilde en çok öne çıkan kavramın her üç okul türünde de geribildirim olduğu görülmektedir. Özellikle IB okullarında dönüşümlü düşünme, farklılaştırma, ihtiyaç belirleme, planlama ve raporlama şeklinde karşılaşılan kavramlarda değerlendirmenin yalnız durum belirleme için yapılmadığı, öğrenme için de değerlendirme yapıldığı ve değerlendirmenin öğrenmeyi de desteklediği söylenebilir. Bu bulgu, Toe et al. (2015) tarafından raporlanan proje sonuçlarında da Güler ve Yaltırık'ın (2011) çalışmalarında da öğretmenlerin IB'nin güçlü yanı olarak ölçme ve değerlendirmeyi görmelerin açısından bu araştırmanın sonuçları ile desteklenmektedir.

"Nasıl ölçeriz?" sorusuna yanıt olacak şekilde devlet okullarında kullanılan ölçme araçlarının sınavlara hazırlık odaklı olduğu, özel okullarda hem sınav hem gelişimin dikkate alındığı görülmüştür. IB okullarında ise sorgulama, becerileri geliştirme temelinde IB öğrenen profiline hizmet edecek şekilde ihtiyaca göre farklılaşan araçların kullanıldığı görülmektedir (IBO, 2018d). Bu bulgu Toe et al. (2015) tarafından raporlanan proje sonuçları ile de benzerlik göstermektedir.

İkinci araştırma sorusuna ilişkin bulgular öğretmenlerin okullarında uyguladıkları bir ölçme ve değerlendirme sistemi olup olmamasını, varsa bu uygulamaları sını içinde nasıl hayata geçirdiklerini içermektedir. Öğretmenlerin okullarında uygulamaları planlanan ölçme ve değerlendirme sistemi, MEB tarafından öğretim programlarının içinde belirtilerek öğretmenlerin ve eğitim uygulayıcılarının yeterliklerine göre serbest bırakılmıştır fakat yapılması gerektiği vurgulanmıştır (MEB, 2013; 2018; 2019). IB okullarında ise ölçme ve değerlendirme uygulamalarının yapılması, kayıt altına alınması ve raporlanması zorunludur (IBO, 2018d). Devlet okulundaki öğretmenlerin \%48'i IB okullarındaki öğretmenlerin \%83'ü özel okullardaki öğretmenlerin \%93'ü okullarında uygulanan bir ölçme ve değerlendirme sisteminin bulunduğunu belirtmiştir. Devlet okullarında bu oranının diğerlerinden 
Merve Yıldırım Seheryeli, Selahattin Gelbal- Uluslararası Eğitim Programları ve Öğretim Çalışmaları Dergisi, 10(1), 2020, 221-260 oldukça az olduğu görülmektedir. Güler ve Yaltırık'ın (2011) ve Toe et al. (2015) de yaptıkları çalışmalarda IB'nin güçlü yanı olarak ölçme ve değerlendirme çalışmalarının IBO yetkilileri tarafından düzenli aralıklarla değerlendirilmesi olarak belirtmişlerdir. Özel okullarda ise okul politikalarına göre bu zorunluluk değişmektedir. Dolayısı ile öğretmenlerin ölçme ve değerlendirme çalışmalarını uygulamaya geçirmeleri ve bu çalışmaları benimsemeleri için bir denetleme mekanizmasına intiyaç duyulduğu söylenebilir.

Çalıştıkları okulda bir ölçme ve değerlendirme sistemi bulunduğunu ve bu sistemi hayata geçirmek için neler yaptıklarını belirten öğretmenler tüm katıımcıların \%69'udur. Katılımcıların ifadeleri "Düzey belirleme", "Öğrenmeyi pekiştirme", "Sistemin niteliğine katkı sağlama”, "Değerlendirme çalışmaları", "Elde edilen bilgilerin kaydedilmesi" başıklarında toplanmıştır.

"Düzey belirleme" çalışmaları yaptıklarını belirten öğretmenlerde okullara göre farklılaşan çalışmaların ise becerilerin ölçülmesi, kazanıma-taksonomiye uygun soru yazma ve yeni nesil sorular olduğu söylenebilir. Bu farklılaşmaların sebebinin özellikle devlet okullarında ve özel okullarda öğrencilerin sınav odaklı hazırlanmaları olduğu söylenebilir. Devlet okulları için elde edilen bu bulgular alanyazındaki diğer çalışmaların (Arda, 2009; Gök \& Şahin, 2009; Yapıcı \& Demirdelen, 2007) bulguları ile de örtüşmektedir. Özel okullarda diğerlerinden farklı vurgulanan kazanıma, taksonomiye uygun soru yazma ile öğrencilerin öğrenmelerinin ya da eksiklerinin hangi bilişsel düzeyde olduğunun da belirlenmeye çalışıldığı görülmektedir.

"Öğrenmeyi pekiştirme" çalışmaları yaptıklarını belirten öğretmenlerde okullara göre farklılaşan çalışmaların ise sorgulama çalışmaları olduğu söylenebilir. Bu durumda devlet okullarında ve özel okullarda öğrenmeyi pekiştirme çalışmalarının geleneksel düzeyde sınırlı kaldığı, IB okullarında ise becerilere odaklanıldığı söylenebilir. Bu durum IB okullarının IBO (2012; 2018b; 2018c; 2018d) tarafından belirtilen felsefeyi okul düzeyinde de benimsediklerinin göstergesidir. Özellikle IB okullarında (Kauffman, 2005) sorgulama temelli çalışmalarla öğrencilerin öğrenmelerini geliştirme sürecinde, öğretmenlerin kazandıkları ulusal-uluslararası çoklu bakış açılarının öğretmenlerin yetkinliklerini de farklılaştırdığı söylenebilir.

"Sistemin niteliğine katkı sağlama" çalışmaları yaptıklarını belirten öğretmenlerde en çok öne çıkan çalışmaların devlet okullarında adaletli olma; özel okullarda bireysel farklııkları dikkate alma ve zümrelerle iş birliği içinde olma; IB okullarında disiplinler arası çalışmalar ve zümrelerle iş birliği, kriterlerin öğrencilerle birlikte hazırlanması ya da onları kriterlerden haberdar etme olduğu görülmektedir. Bu durumun IBO'nun (2012) beklentileri ile örtüştüğü, IB okullarında tüm eğitim durumlarının diğer zümrelerle temalara hizmet edecek şekilde iş birliği içinde öğrenen merkezli hazırlanmasından kaynaklandığı düşünülmektedir. Özellikle devlet okulları ve özel okullardaki öğretmenlerin uygulamaları incelendiğinde adaletli olma, ar-ge ekibi, kelebek sistem ya da Web 2.0 araçları gibi çalışmalara yöneldikleri görülmektedir. Bu durumda öğretmenlerin sistemin niteliğine katkı sağlayabilmek için daha etkili desteğe ihtiyaç duydukları söylenebilir.

"Değerlendirme" çalışmaları yaptıklarını belirten öğretmenlerde en çok öne çıkan çalışmalar devlet okullarında geribildirim ve performans değerlendirmedir. Özel okullarda ise geribildirim ve süreç odaklı değerlendirme iken IB okullarında rubrik ve süreç odaklı değerlendirme olmuştur. Bu durumda her üç okulda da değerlendirme çalışmalarında sürece yönelik çalışmalar yapıldığı söylenebilir.

"Elde edilen bilgileri kaydetme" çalışmaları yaptıklarını belirten öğretmenlerde analiz, raporlama gibi çalışmalardan birer kez bahsedilmiş olsa da planlama ve eğitimi planlama çalışmaları özellikle IB 
Merve Yıldırım Seheryeli, Selahattin Gelbal- Uluslararası Eğitim Programları ve Öğretim Çalışmaları Dergisi, 10(1), 2020, 221-260 okullarında öne çıkmıştır. Bu durumun sebebinin IB okullarının akreditasyonlarının devamı için değerlendirilmesi (Güler \& Yaltırık, 2011; Toe et al.,2015) olduğu söylenebilir. Dolayısı ile program değerlendirme çalışmalarının özellikle uygulamadaki takiplerinin de sistemli bir şekilde yapılmasının önemli olduğu görülmektedir. Buna ek olarak hizmet içi eğitim çalışmalarda özellikle ölçme sonuçlarına göre eğitimi planlama üzerine odaklanılmasının bu okullar arasındaki farkların giderilmesine de yardımcı olacağı düşünülmektedir.

Üçüncü araştırma sorusuna ilişkin bulgularda öğretmenlerin verilen 10 ölçme ve değerlendirme araç ve tekniğini kullanma, elde ettikleri bilgileri kaydetme, bu bilgileri öğrencilerle ve velilerle paylaşma sıklıkları okullara göre karşılaştırılmıştır.

Gelbal ve Kelecioğlu'nun (2007) öğretmen görüşlerini inceledikleri çalışmalarında öğretmenlerin daha çok geleneksel yöntemleri tercih ettiği, öğrencilerin kendilerini değerlendirmesine yönelik yöntemleri en az sıklıkla kullanıldığını belirtmişlerdir. Bu durum; öğretmenlerin araç ve yöntemleri kullanma sıklıkları incelendiğinde öğrencileri gözlemleme, geribildirim, performans değerlendirme (sunum, tartışma, rol yapma, vb.), çoktan seçmeli sorular, açık uçlu görevler, portfolyo kullanma sıklıklarının okullar arasında farklılaşmadığı bulgusu ile çeliş̧mektedir. Bu durumun sonucu olarak günümüzde öğretmenlerin tamamlayıcı ölçme ve değerlendirme yaklaşımlarını da eğitim sürecinin bir parçası olarak daha fazla görmeye başladıkları söylenebilir.

Öğretmenlerin elde ettikleri bilgileri kaydetme sıklıkları incelendiğinde çoktan seçmeli sorular ve açık uçlu görevleri kaydetme sıklıklarının okullar arasında farklılaşmadığı; öğrencileri gözlemleme, geribildirim, performans değerlendirme (sunum, tartışma, rol yapma, vb.), portfolyo, öz ve akran değerlendirme, kontrol listesi, puanlama anahtarı (Rubrik) kaydetme sıklığının IB okullarında diğer okullardan fazla olduğu görülmüştür. Bu bulgu Toe et al. (2015) tarafından hazırlanan raporda, öğretmenlerin farklı değerlendirme araçlarını birlikte kullandıkları, gelişimsel süreklilik kavramını benimseyerek elde ettikleri bilgileri kayıt altına aldıkları görüşleri ile de örtüşmektedir.

Öğretmenlerin elde ettikleri bilgileri öğrencilerle paylaşma sıklıkları incelendiğinde ise geribildirim dışındaki tüm araç ve yöntemlerde farklılaşma olduğu; bu sıklığın IB okullarında diğer okullardan fazla olduğu görülmüştür. Özellikle özel okullardaki ve devlet okullarındaki öğretmenlerin değerlendirmeyi not verme ya da kendi eğitim durumlarını gözden geçirmede kullandıkları söylenebilir. Fakat öğrencilerin kendi öğrenmelerine yön vermeleri için bu sonuçlardan haberdar olmaları da gerekmektedir. Velilerle paylaşma sıklıkları incelendiğinde ise öğrencileri gözlemleme ve performans değerlendirme dışındaki tüm araç ve yöntemlerde farklılaşma olduğu; çoktan seçmeli sorular ve akran değerlendirmede bu sıklığın özel okullarda daha fazla, diğer araç ve yöntemlerde bu sıklığın IB okullarında daha fazla olduğu görülmüştür. Özellikle geribildirimin öğrenciye yapılma sıklığı farklılaşmazken velilere yapılma sıklı̆ının farklılaştığı dikkat çekmektedir. Toe et al. (2015) raporunda hem öğrenciye hem de velilere öğrenciyi kişisel olarak övmek yerine etkili geribildirim yapılmasının önemini vurgulamıştır.

Tüm bulgular birlikte değerlendirildiğinde devlet okullarındaki, özel okullardaki ve IB okullarındaki öğretmenlerin sınıf içi uygulamalarının okulun amaçlarına göre farklılaştığı görülmektedir. Bu nedenle MEB'in ya da her okulun "ölçme ve değerlendirme"den beklentilerinin açıkça ve yazılı olarak belirtildiği, örnek uygulamaların ve yapılacak çalışmaların öğretmenlere tüm ayrıntıları ile birlikte verildiği öğretim programlarının kullanılması öğretmenlerin işlerini benimsemesini sağlayarak nitelikli ölçme ve değerlendirmelerin yapılmasını sağlayacaktır. Yine öğretmenlerin ihtiyaç duydukları ölçme ve 
Merve Yıldııım Seheryeli, Selahattin Gelbal- Uluslararası Eğitim Programları ve Öğretim Çalışmaları Dergisi, 10(1), 2020, 221-260 değerlendirme ve geribildirimlerle öğrencilerin öğrenmelerinin geliştirilmesinde desteğin sağlanabilmesi için okullarda ölçme ve değerlendirme, program geliştirme uzmanlarının bulunması önerilebilir. Bu sayede sonuç ve süreç birlikte, bireysel farklılıklar göz önüne alınarak üst düzey düşünme becerilerinin ölçülmesi ve geliştirilmesi için gereken destek de sağlanabilir. Benzer şekilde okullar denetlendiğinde ölçme ve değerlendirme araç ve yöntemlerini kullanma sıklıkları da artmaktadır. Dış denetleyiciler oluşturulup her okulun denetlenmesi sağlanarak ölçme ve değerlendirme uygulamalarında hesap verilebilirlik sağlanmış olacaktır. Bu bulguların nedenlerinin daha ayrıntılı olarak araştırılması gerekmektedir. Son olarak IB okullarında yapılan çalışmalara benzer olarak devlet okullarında ve özel okullarda da çalışmalar yapılabilir, eylem araştırmaları ile bu çalışmaların etkililikleri de değerlendirilebilir. 
Arda, D. (2009). Illöğretim sınıf öğretmenlerinin 2005 öğretim programı ekseninde ölçme ve değerlendirme alanındaki yeterlilik ve görüşlerinin incelenmesi. Unpublished master's thesis, Marmara Üniversitesi, İstanbul.

Ateş, M. (2011). IBDP (International Baccalaureate Diploma Programme) in Turkey and its Geography Content. Marmara Geographical Review, (23), 111-134.

Ayyıldız, E., \& Üzümcü, Ö. (2016). An Alternative for international education: International Baccalaureate Primary Years Programme (IBPYP). International Journal of Early Childhood Education Studies, 1(2) , 64-73.

Baysen, F., Baysen, E., \& Çakmak, N. (2017). The Effect of International Baccalaureate Program on High School Students' Misconceptions Regarding Plagiarism. Information World, 18(1), 29-47. DOI: 10.15612/BD.2017.576

Bora, N. (2010). Uluslararası Bakalorya diploma programının (IB) öğretmen ve öğrencilerin öğrenme iklimi ile ilgili algıları üzerindeki etkisi. Unpublished master's thesis, Maltepe Üniversitesi, istanbul.

Büyükgenç, F. Y. (2014). Uluslararası Bakalorya Diploma Programı mezunlarının programa ilişkin görüşleri. Unpublished Doktoral Thesis, Ankara Üniversitesi, Ankara.

Büyüköztürk, Ş., Çakmak, E. K., Akgün, Ö. E., Karadeniz, Ş., \& Demirel, F. (2019). Bilimsel araştırma yöntemleri. Ankara: Pegem Akademi.

Demirel, Ö. (2012). Eğitimde program geliştirme kuramdan uygulamaya. Ankara: Pegem Akademi.

Erden, M. (1998). Eğitimde program değerlendirme. Ankara: Anı Yayıncılık.

Erdoğan, M., Kayır, Ç. G., Kaplan, H., Ünal, Ü. Ö. A., \& Akbunar, Ş. (2015). Teachers views on curriculum developed since 2005: A content analysis of the researches between 2005 and 2011. Kastamonu Education Journal, 23(1), 171-196.

Ertürk, S. (2013). Eğitimde "Program" Geliştirme. Ankara: Edge Akademi.

Gelbal, S., \& Kelecioğlu, H. (2007). Teachers' proficiency perceptions of about the measurement and evaluation techniques and the problems they confront. Hacettepe University Journal of Education, 33(33), 135-145.

Güler, T., \& Yaltırık, i. (2011). A review of primary years program in early childhood education according to teacher's views. Education and Science Journal, 36(160).

International Baccalaureate Organization (IBO). (t.y.). Find an IB World School. Retrieved from https://www.ibo.org/programmes/find-an-ibschool/?SearchFields.Country=TR

International Baccalaureate Organization (IBO). (2012). Primary Years Programme Developing a transdisciplinary programme of inquiry. United Kingdom: IBO Ltd.

International Baccalaureate Organization (IBO). (2018a). Primary Years Programme Learning and teaching. United Kingdom: IBO Ltd.

International Baccalaureate Organization (IBO). (2018b). The Learner. United Kingdom: IBO Ltd. 
Merve Yıldırım Seheryeli, Selahattin Gelbal- Uluslararası Eğitim Programları ve Öğretim Çalışmaları Dergisi, 10(1), 2020, 221-260 International Baccalaureate Organization (IBO). (2018c). Supporting student agency. United Kingdom: IBO Ltd.

International Baccalaureate Organization (IBO). (2018d). Assessment principles and practices-Quality assessments in a digital age. United Kingdom: IBO Ltd.

Kauffman, N. (2005). Variations on a Theme: Implementation of the International Baccalaureate Primary Years Programme. Journal of Research In International Education, 4(3), 243-261. DOI: $10.1177 / 1475240905057798$

Keleş, A. B. (2013). Ankara ilinde Uluslararası Bakalorya Diploma Programı'na dâhil olan ve olmayan on ikinci sınıf öğrencilerinin okuma alışkanlıkları ve okumaya yönelik tutumları. Unpublished master's thesis, Bilkent Üniversitesi, Ankara.

Kocabaş, E. Ö., \& Akkök, F. (2016). Comparing students in the international bacholar and the regular lycee program on the family communication patterns and the social skills acquired. Turkish Psychological Counseling and Guidance Journal, 3(27).

Millî Eğitim Bakanlığı (MEB). (2019). Mutlu Çocuklar Güçlü Türkiye 2023 Eğitim Vizyonu. Retrieved from http://2023vizyonu.meb.gov.tr/

Millî Eğitim Bakanlığı (MEB). (2013). Okul Öncesi Eğitim Programı. Retrieved from http://mufredat.meb.gov.tr/Programlar.aspx

Millî Eğitim Bakanlığı (MEB). (2018). Matematik Dersi Öğretim Programı. Retrieved from http://mufredat.meb.gov.tr/Programlar.aspx

Millî Eğitim Bakanlığı (MEB). (2019). Türkçe Dersi Öğretim Programı. Retrieved from http://mufredat.meb.gov.tr/Programlar.aspx

Millî Eğitim Bakanlığı Özel Öğretim Kurumları Yönetmeliği (2012, 20 Mart). Resmi Gazete (Sayı: 28239). Retrieved from https://ookgm.meb.gov.tr/meb_iys_dosyalar/ 2019_11/04164227_ozel_ogretim_kurumlari_yonetmeligi.pdf

Millî Eğitim Bakanlığı (MEB). (2019). Millî Eğitim İstatistikleri Örgün Eğitim 2018-2019. Retrieved from http://sgb.meb.gov.tr/www/icerik_goruntule.php?KNO=361

Oraz, B. (2019). Ulusal eğitim programından Uluslararası Bakalorya (IB) eğitim programına geçişte yöneticilerin liderlik zorlukları. Unpublished master's thesis, Maltepe Üniversitesi, İstanbul.

Senemoğlu, N. (2012). Gelişim, öğrenme ve öğretim. Ankara: Pegem Akademi.

Şanver, M. (2016). Öğretmen ve okul yöneticilerinin görüşlerine göre Uluslararası Bakalorya Okullarında değerler eğitimi açısından okul ortamı. Journal of Faculty of Theology of Uludağ University, 25(2), 81-96.

Toe, D., Lang, J., Paatsch, L., Yim, B., Jobling, W., Doig, B., \& Aranda, G. (2015). (Final Report). Assessment of student development and learning in IB PYP Schools. Deakin University, School of Education.

Twigg, V. V. (2010). Teachers' practices, values and beliefs for successful inquiry-based teaching in the International Baccalaureate Primary Years Programme. Journal of Research in International Education, 9(1), 40-65. DOI: 10.1177/1475240909356947 
Merve Yıldırım Seheryeli, Selahattin Gelbal- Uluslararası Eğitim Programları ve Öğretim Çalışmaları Dergisi, 10(1), 2020, 221-260 Yapıcı, M., \& Demirdelen, C. (2007). Teachers' views on primary school 4th grade social studies curriculum. Elementary Education Online, 6(2), 204-212.

Yüksel, İ., \& Sağlam, M. (2014). Eğitimde program değerlendirme. Ankara: Pegem Akademi. 
Merve Yıldırım Seheryeli, Selahattin Gelbal- Uluslararası Eğitim Programları ve Öğretim Çalışmaları Dergisi, 10(1), 2020, 221-260 